\title{
Application of Fly Ash as an Adsorbent for Removal of Air and Water Pollutants
}

\author{
Jun Cong Ge ${ }^{1}$, Sam Ki Yoon ${ }^{2, *}$ and Nag Jung Choi ${ }^{1, *}$ (i) \\ 1 Division of Mechanical Design Engineering, Chonbuk National University, 567 Baekje-daero, \\ Jeonjusi 54896, Jeollabuk-do, Korea; freedefeng@naver.com \\ 2 Department of Convergence Technology Engineering, Chonbuk National University, \\ 177 Sandannambuk-ro, Gunsan-si 54001, Jeollabuk-do, Korea \\ * Correspondence: sky596072@hanmail.net (S.K.Y.); njchoi@jbnu.ac.kr (N.J.C.); Tel.: +82-63-270-4765 (N.J.C.)
}

Received: 11 June 2018; Accepted: 4 July 2018; Published: 10 July 2018

\begin{abstract}
Air pollutants such as volatile organic compounds (VOCs), nitrogen oxides (NOx), and sulfur dioxide $\left(\mathrm{SO}_{2}\right)$, as well as water pollutants (e.g., heavy metals phosphorous, fluoride, boron, phenolic compounds, and dyes), are harmful to humans and the environment. Effective control and reduction of their pollution is therefore an important topic for today's scientists. Fly ash (FA) is a type of industrial waste that can cause multiple environmental problems if discharged into the air. On the other hand, because of its high porosity, large specific surface area, and other unique characteristics, FA can also be used as a low-cost and high efficient adsorbent for treatment of environment pollutants. This paper reviews the effects of FA on treatment of the air and water pollution, including to the current status of global FA utilization, physicochemical properties, principle of adsorption, and the application direction of FA in the future. Since most researchers only studied the adsorption capacity of pure FA or zeolite (synthesized from FA), the research on the fabrication of nanofiber membranes using FA is still lacking, especially the adsorption of VOCs from air and heavy metals from wastewater using FA nanofiber membranes. Therefore, in this paper, we focus on reviewing and summarizing that FA can be spun into a fiber membrane via electrospinning with the ability to adsorb VOCs and heavy metals from air and wastewater. Moreover, we also evaluate the future application value of FA nanofiber membranes in the field of environmental pollution control. Utilization of nanofiber technology to fabricate multi-functional FA emerging composite materials to mitigate air and water pollution has great potential in the future, especially the use of pollutant materials to control other pollutants.
\end{abstract}

Keywords: fly ash; composite material; environmental pollution; volatile organic compounds; heavy metal

\section{Introduction}

Along with unceasing economic development, people's living standard enhances, and humans currently live in a time of rapid development, with daily life constantly becoming more high-tech and intelligent. However, the continuous improvement of human life will inevitably increase the demand for energy and other substances, and it will cause some environmental pollution problems, such as air and water pollutants including nitrogen oxides (NOx) [1], volatile organic compounds (VOCs) [2], sulfur dioxide $\left(\mathrm{SO}_{2}\right)$ [3], and heavy metal pollution [4]. Fly ash (FA), a type of industrial waste, is a coal combustion product composed of particulates [5]. With rapid industrial development, large demand for electricity has led to hundreds of millions of tons of FA (around $80 \%$ of which is fly ash) being discharged every year worldwide. The annual coal consumption of China in 2015 was about $50 \%$ of the global coal consumption [6]. Power generation using coal provides energy for daily life and industry, but it also produces atmospheric and water pollution, which disrupts ecological cycles. 
FA pollutes the atmosphere and threatens human health if it is discharged directly from power plant chimneys into the atmosphere without treatment $[7,8]$. This is a significant contributor to recent air quality and haze problems in China [9,10].

However, with developing science and technology, FA from power plants is changing from industrial waste into an industrial raw material [11-13]. FA is a large porous structure exhibiting an irregular shape, with large specific surface areas and high adsorption activities. The characteristics of FA mainly depend on the type of coal and the combustion conditions [14,15]. Yao et al. pointed out that the average diameter of FA in the form of fine particles is less than $20 \mu \mathrm{m}$, and their bulk density and specific surface area are in the range of $0.54-0.86 \mathrm{~g} / \mathrm{cm}^{3}$ and $300-500 \mathrm{~m}^{2} / \mathrm{kg}$, respectively [15]. In addition, FA contains valuable oxide components, such as $\mathrm{SiO}_{2}, \mathrm{Al}_{2} \mathrm{O}_{3}, \mathrm{CaO}, \mathrm{MgO}, \mathrm{Na}_{2} \mathrm{O}$, and $\mathrm{TiO}_{2}$, and essential elements, including $\mathrm{P}, \mathrm{K}, \mathrm{Mg}, \mathrm{Zn}, \mathrm{Fe}, \mathrm{Mn}$, and others [5,7]. Therefore, FA has attracted the attention of many researchers. FA is a pozzolanic mixture formed by high temperature combustion of pulverized coal. Its chemical composition is similar to clay, with a good lime binding capacity. Thus, it is primarily used for production of cement [16], clay bricks [17], hollow blocks [18], aerated concrete [19], and other building materials [20-22]. It can also be used as an agricultural fertilizer and soil conditioner due to its low bulk density, high water retention capacity, favorable $\mathrm{pH}$, and other properties [15,23,24]. Ram et al. [25] studied the effects of FA on rice crop production from 1996 to 2000 and found that FA improved texture, fertility, and crop productivity of mine spoil. Figure 1 shows the various applications of FA in different fields.

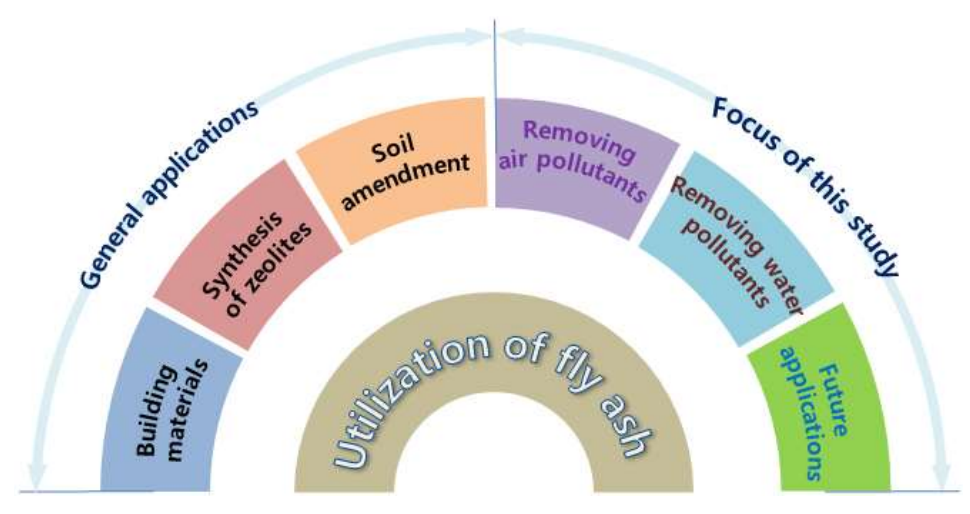

Figure 1. Various applications of fly ash in different fields.

FA can also be used as a low-cost adsorbent because of its excellent specific surface area, porosity, particle size [26], and other natural characteristics [27]. Bhattacharyya et al. [28] found that FA could be used as an adsorbent in a cascade with a plasma reactor to NOx emission from biodiesel engines. Hower et al. [29] showed that FA carbon captures $\mathrm{Hg}$ efficiently. Other researchers have found that, after simple modification, FA is a good adsorbent of $\mathrm{SO}_{2}$ [30] and VOCs [31]. Furthermore, one-step fabrication of FA into a fibrous membrane by electrospun technology to adsorb VOCs from air has been successfully reported by our research group [32,33]. On the other hand, FA can also be combined with $\mathrm{TiO}_{2}$ [34] or $\mathrm{AgNO}_{3}$ [35] to produce a multifunctional fibrous membrane under electrospinning for purifying water, such as adsorption of heavy metals $(\mathrm{Hg}$ and $\mathrm{Pb}$ ), removal of dyes (methylene blue), antibacterial activity, carcinogenic arsenic (As) and toxic organic dyes. To sum up, FA can be fabricated into a variety of composite materials including zeolites and fiber membranes. They have excellent adsorption capacity in controlling air and water pollutants, such as VOCs, SOx, NOx, heavy metals and toxic organic dyes. In addition, the perfect combination of nanotechnology and FA can reduce environmental pollution while producing low-cost and high-performance nanocomposites. 


\section{Global Overview of Fly Ash}

\subsection{China}

China is a populous country with high electricity consumption per capita. Coal is one of the main energy sources in China, accounting for 70\% of the total energy consumption from 1978 to 2009 [36]. China is the largest coal mining and consuming country in the world, and it has surpassed Japan to become the world's largest coal-importing country in 2008 [36]. China consumed more than 3 billion tons of coals in 2010 [37], and most cities in northern China use coal-fired heating in the winter. Figure 2 shows the coal consumption of China compared with other countries and its relationship with Gross Domestic Product (GDP). China clearly is dependent on energy from coal. However, burning coal produces FA in the air that causes environmental problems such as acid rain, fog and haze, and heavy metal pollution [38-40]. Solving the problem of FA pollutant from burning coal would be a great contribution to environmental and human health.

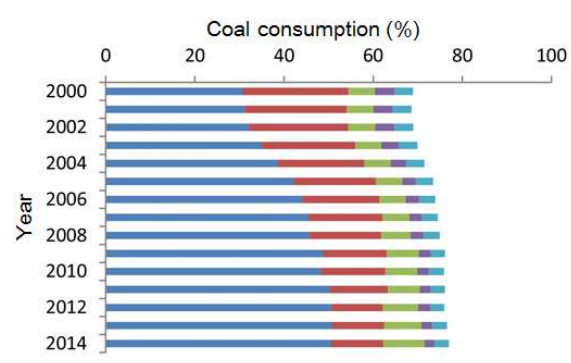

(a)

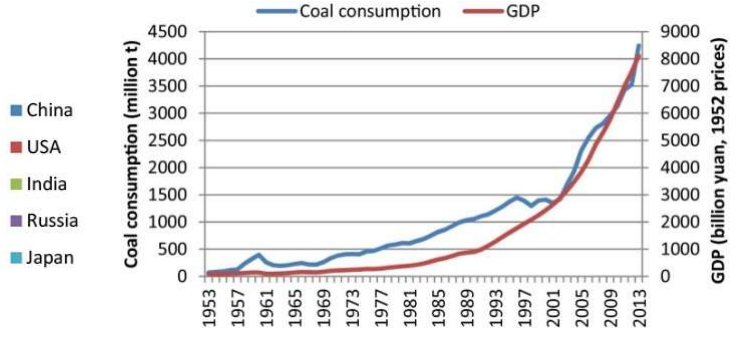

(b)

Figure 2. Comparison of coal consumption in China with other important coal consuming countries (a); and relationship between coal consumption and GDP in China (b) (reproduced with permission from [36], Elsevier, 2018).

Figure 3 shows the production and utilization rate of FA from 2001 to 2015 and the degree of utilization of FA in different cities of China in 2010. The annual output of FA is huge in China. At the end of 2015, about 580 million tons of FA were produced, accounting for about $77 \%$ of the global FA production [41]. FA utilization in China increased after 2004 and reached about $70 \%$ in 2015 (Figure 3a), which is closely related to the rapid development of China's economy and technology. However, different statistical offices have different estimates of the utilization rate of fly ash in China. For example, Greenpeace [41] estimated the utilization rate to be only 30\%. Regardless of the value, the utilization rate of FA in China is very high. According to statistics, the global average utilization rate of FA is about 25\% [42]. Other researchers reported that the utilization rate of FA is about $67 \%$ [43]. The utilization rate of FA in different cities in China is shown in Figure 3b. The utilization rate of fly ash in eastern China is clearly higher than in western China, due to the large market for FA in the east [37]. The specific utilization of FA is shown in Table 1. Although there are many ways to utilize FA in China, few technologically advanced products use FA. If processes involving FA are not strictly controlled, they can cause secondary pollution [37].

Table 1. Specific utilization of fly ash in China.

\begin{tabular}{ll}
\hline \multicolumn{1}{c}{ Item } & \multicolumn{1}{c}{ Specific Utilization } \\
\hline Building materials & Cement, fly ash bricks, fly ash ceramics, fly ash blocks, concrete, mortar \\
Road construction & Embankments, pavement bases and pavement \\
& Structure backfill, construction backfill, filling in low-lying areas and \\
Backfill & wastelands, filling mines, filling coal mining subsidence areas, building \\
& materials for pits, tidal marshes \\
Agriculture & Soil improvement, fertilizer production, land reclamation \\
Recycling useful raw materials & Hollow microspheres, $\mathrm{Al}_{2} \mathrm{O}_{3}, \mathrm{Fe}_{2} \mathrm{O}_{3}, \mathrm{SiO}_{2}$, carbon granules \\
\hline
\end{tabular}




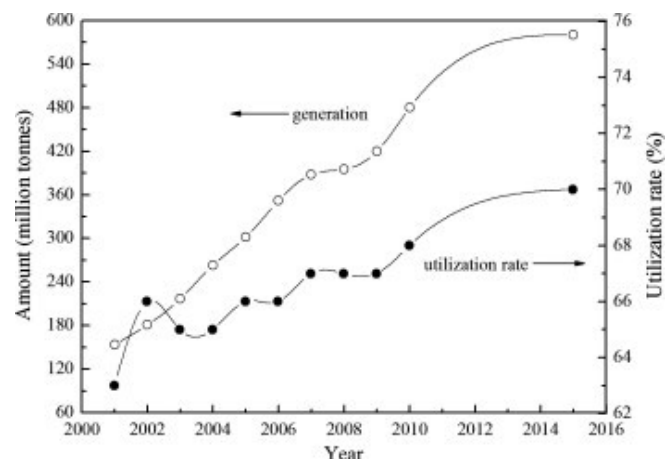

(a)

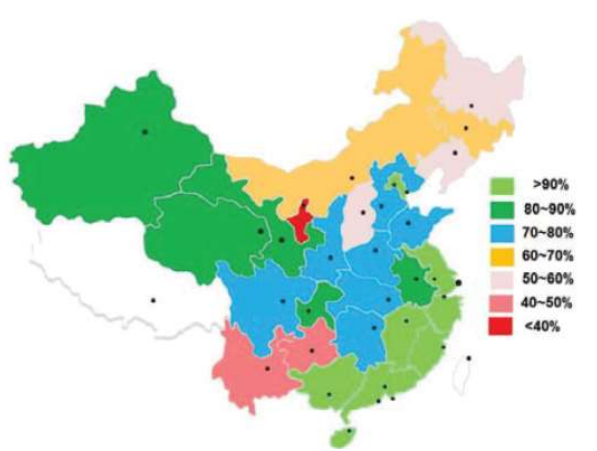

(b)

Figure 3. Production and utilization of fly ash from 2001 to 2015 (reproduced with permission from [41], Elsevier, 2018) (a); and comprehensive utilization rate of fly ash in Chinese cities in 2010 (reproduced with permission from [37], Elsevier, 2018) (b).

\subsection{India}

With the development of economy and the increase of the population, the energy consumption in India is also increasing year by year. U.S. Energy Information Administration Department reported that the energy consumption growth in India will far exceed that of China, the United States, and Russia until the end of 2035 [44]. In terms of generating capacity, Indian power plants rely mainly on fossil fuels. In general, $76.4 \%$ of the power generation is coal-based power plants, while renewable energy sources only generate $6.62 \%$ [44]. Annual production of FA in India is therefore also increasing rapidly. Production of FA during 2010 and 2011 increased to about 130 million tons, which was about $85.7 \%$ higher than during 1996 to 1997 . The FA utilization rate also increased from $9.63 \%$ in 1996 to 1997 to $54.53 \%$ in 2010 to 2011, an increase of $466 \%$ over a 15 year period [45]. This shows that people are aware of the value of FA utilization with technological advances and increased incomes. Figure 4 shows uses of FA in India: $44.76 \%$ for cement, $16.72 \%$ for reclamation, $9.1 \%$ for mine filling, $6.89 \%$ for ash dyke raising, $6.86 \%$ for bricks and tiles, $6.51 \%$ for road and embankments, $0.74 \%$ for concrete, and $7.38 \%$ for other uses [15]. The Ministry of Environment, Forests and Climate Change (MoEFCC) expanded the standard of using FA to make it more used in agriculture. Moreover, to improve the utilization of FA and reduce the cost, the Ministry of Railways has also made relevant regulation policies, such as providing FA free of charge to the surrounding users, and establishing the cement industry near coal power plant [46]. Parab et al. [47] and other researchers [48-52] found that FA of India can improve soil structure and be used to reclaim dumps and degraded soils by making soil more fertile and increasing the yield of agricultural products. Given the advantages of FA and the policies in place in India, it is expected that the utilization rate of FA in India will continue to increase in the near future.

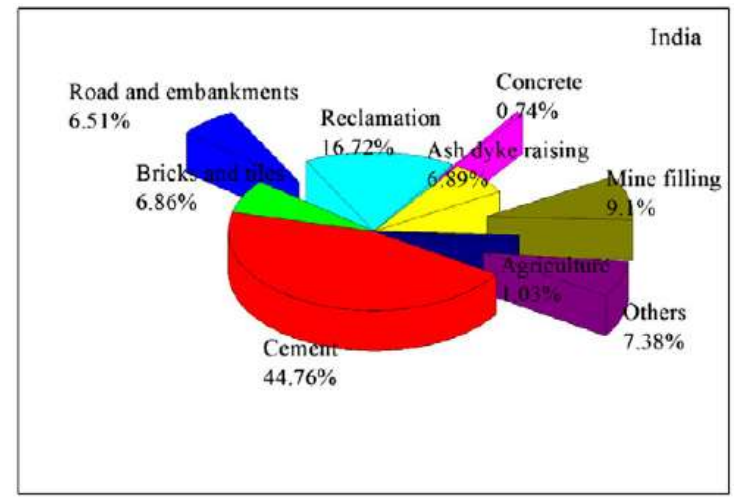

Figure 4. Utilization of fly ash in India (reproduced with permission from [15], Elsevier, 2018). 


\subsection{USA}

The United States has multiple energy sources and high energy efficiency due to their advanced technology and equipment. Americans use many types of energy, including petroleum, natural gas, coal, renewable energy, and nuclear electric power. The energy consumption of the United States in 2016 is displayed in Figure 5a. Coal consumption accounted for only 15\% of total United States primary energy consumption. Natural gas and renewable energy accounted for 39\% of total energy. Although renewable energy only accounted for $10 \%$, it includes many sources such as biomass waste, biofuel, and hydroelectric. It can be inferred that the United States has a strong sense of environmental protection, which makes it particularly favor use of clean energy based on advanced technology. Because of these factors, coal-fired power generation in the United States is not substantial. The energy consumption for power stations in 2013 is shown in Figure 5b. It can be clearly seen that the United States relies mainly on natural gas to generate electricity, which accounts for about $50.8 \%$ of energy production. Coal accounts for only $21.9 \%$ of all power generation. The growth rate of coal consumption in the United States from 2010 to 2017 is almost zero, as shown in Figure 6. Basu et al. [24] presented that utilization of FA in the United States is as high as $65 \%$, including many fields, such as mine fill, cement, wallboard, snow and ice control, agriculture, cosmetics, bowling balls and carpeting. In 2006, the use of FA in cement kilns was about four times more than that in 2001, about 4 million tons. In addition, housing projects and rising demand in the ready-mixed concrete market are expected to be major drivers for future FA utilization in the United States [53].

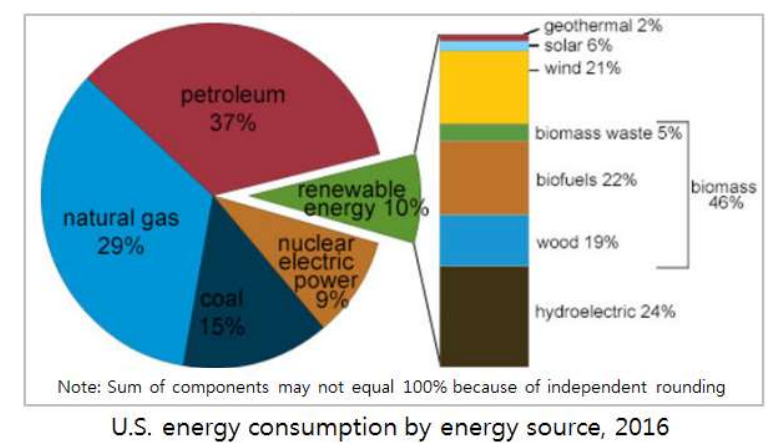

(a)

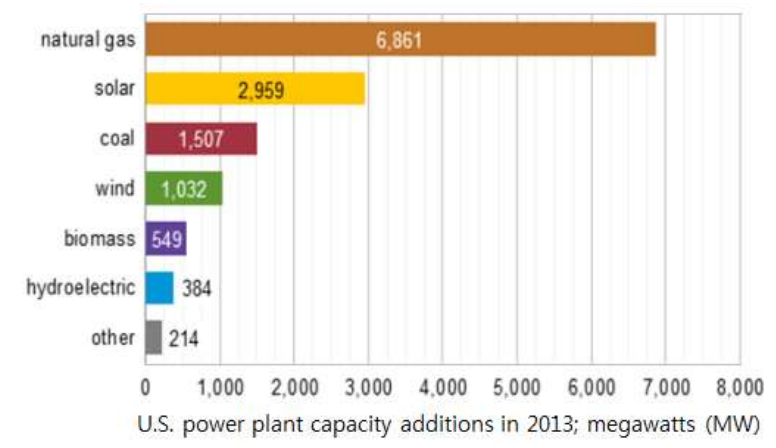

(b)

Figure 5. Energy consumption in the United States in 2016 (sources: EIA; U.S. energy consumption by energy source, 2016) (a); and energy consumption of power stations in the United States in 2013 (sources: EIA; U.S. power plant capacity additions, 2013) (b). 


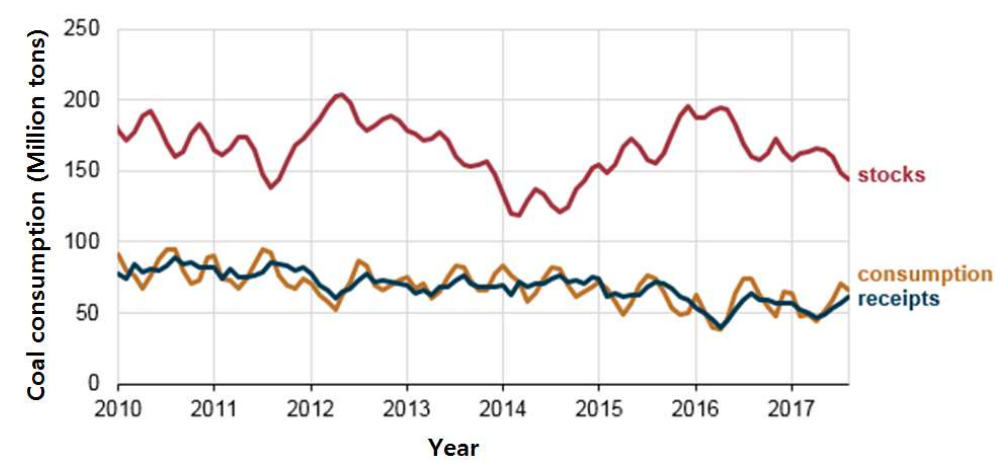

Figure 6. Coal consumption in the United States from 2010 to 2017 (sources: EIA; U.S. Energy Information Administration, Electric Power Monthly).

\subsection{Other Countries}

Other countries produce a small amount of FA from coal-fired power. For example, Germany produces 40 million tons per year, the UK produces 15 million tons, and Australia produces 10 million tons. The annual production of FA has not reached 10 million tons per year in Canada, France, Denmark, Italy, or the Netherlands. These countries produce very little FA every year compared to China and India, but their FA utilization is high. The average utilization rate of Germany, the UK, Australia, Canada, and France is $76 \%$. The average of Denmark, Italy, and the Netherlands is up to $100 \%$. FA is used in the same ways in these countries as in China, India, and USA [24,47,54].

\section{Physical and Chemical Properties of Fly Ash}

The physical and chemical properties of FA play an important role in its study, including its morphology, its chemical properties and its mineralogical properties. FA properties may vary depending on combustion conditions and collector setup. The average size of FA fine particles is less than 20 microns, with a bulk density of $0.54-0.86 \mathrm{~g} / \mathrm{cm}^{3}$, a surface area of $300-500 \mathrm{~m}^{2} / \mathrm{kg}$, and a pH value of 1.2-12.5, with most ashes tending toward alkalinity [55]. FA can be classified into three main groups: acidic ash ( $\mathrm{pH} \sim 4.5)$, mildly alkaline ash ( $\mathrm{pH} 8-9)$, and strongly alkaline ash ( $\mathrm{pH} 11-13)[15,56]$.

\subsection{Morphological Characteristics}

Figures 7 and 8 show scanning electron microscopy (SEM) images of FA. Figure 7a,b shows the morphological characteristics of non-carbonated FA, including different sized spherical particles, cenospheres, and plerospheres. Most of the small particles are well-rounded and solid spheres. Some large particles are vesicular cenospheres due to the presence of gas bubbles or vapor [57]. Figure 7c,d shows morphologies after FA carbonization, which has the "cubic-like" structures of calcite (Figure 7c) and "needle-like" structures of aragonite (Figure 7d). In addition, FA particles are reported to be globular and irregular with high porosity [58], glassy cenospheres [59,60], spherical-shaped and flake-like particles [61,62], spherical particles of varying sizes and particles of unburned coal [59,63,64], and predominantly spherical in shape and consisting of solid spheres, cenospheres, irregular-shaped debris and porous unburnt carbon [15]. In Figure 8, the FA particles are mainly spherical, consisting of solid spheres, cenospheres, irregular fragments and porous unburned carbon. The morphological characteristics of FA depend on particle size, but cenospheres are an exception. FA precipitators are sized 20-53 $\mu \mathrm{m}$ and 75-106 $\mu \mathrm{m}$, while cenospheres are 20-45 $\mu \mathrm{m}$ and 106-150 $\mu \mathrm{m}$ [59]. FA particles smaller than $20 \mu \mathrm{m}$ consist of mostly smooth spherical particles, while many irregularly shaped grains are between 75 and $106 \mu \mathrm{m}$, and fewer irregularly shaped vesicular grains are more than $150 \mu \mathrm{m}$ [65]. 


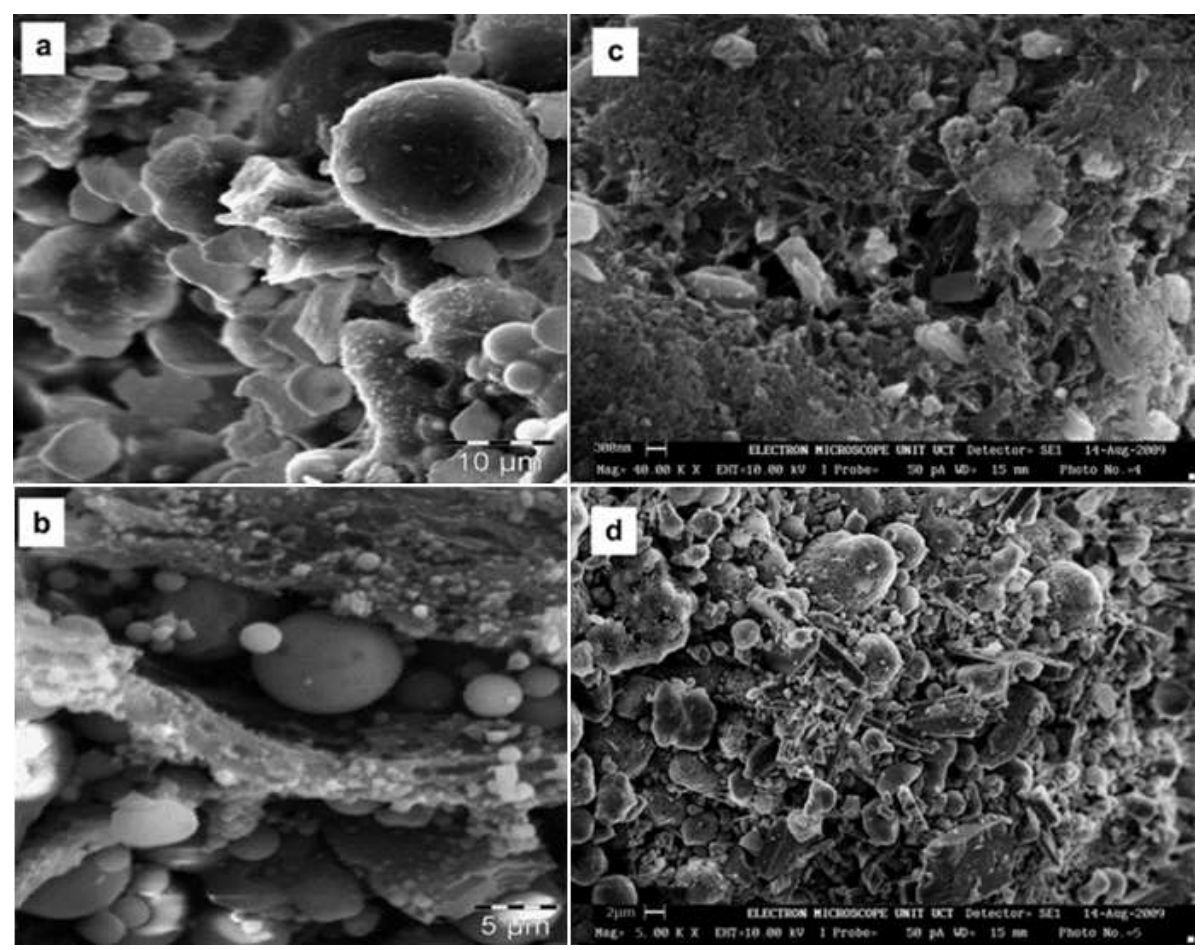

Figure 7. SEM images of: non-carbonated fly ash $(\mathbf{a}, \mathbf{b})$ and carbonated fly ash $(\mathbf{c}, \mathbf{d})$ (reproduced with permission from [57], Elsevier, 2018). Note: The fly ash was collected from coal burning power plants in the Mpumalanga province of South Africa.

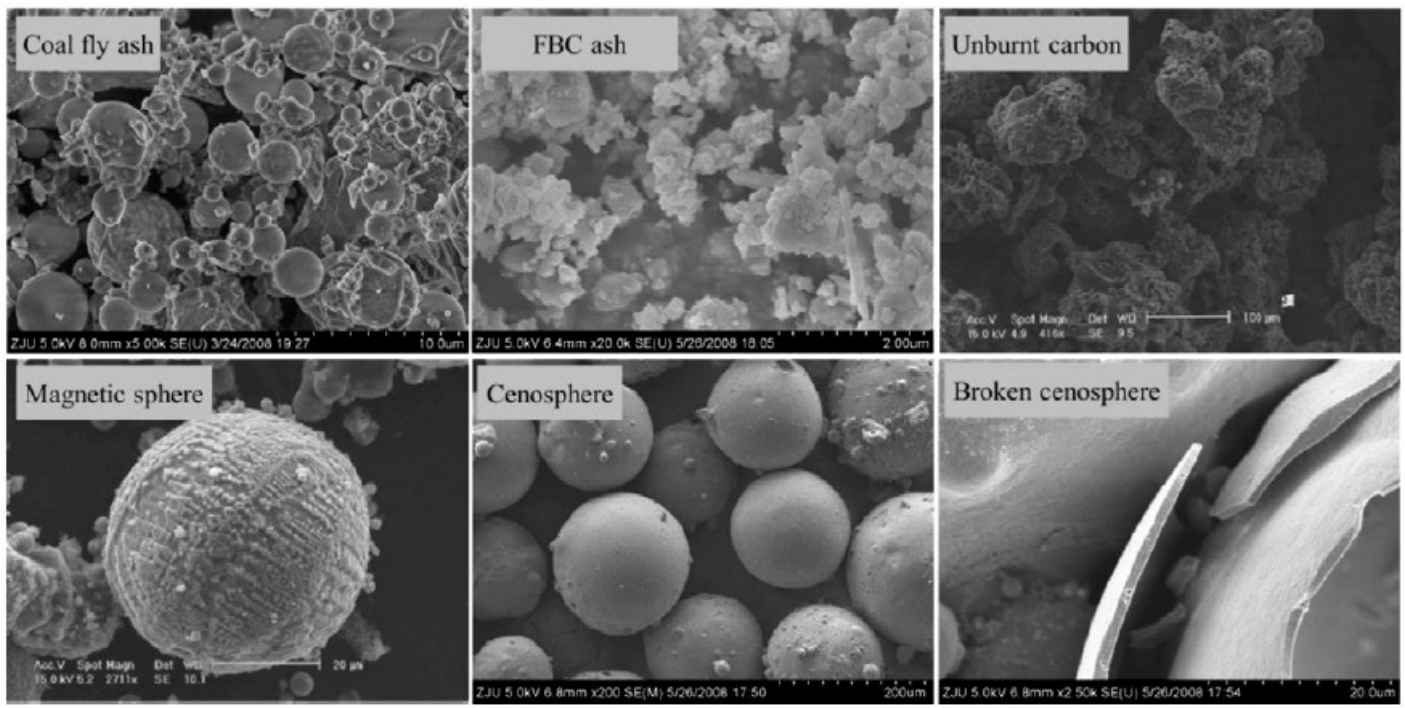

Figure 8. SEM images of fly ash fractions. FBC ash, fluidized bed combustion ash (reproduced with permission from [15], Elsevier, 2017).

\subsection{Chemical and Mineralogical Composition}

The chemical and mineralogical composition of FA plays an important role in the analysis of the application and disposal of FA, including its use as a cement replacement material. The chemical composition of FA can be determined by X-ray fluorescence (XRF) and spectrometry techniques. Researchers [66-70] have reported that FA is composed of $\mathrm{SiO}_{2}, \mathrm{Al}_{2} \mathrm{O}_{3}, \mathrm{Fe}_{2} \mathrm{O}_{3}, \mathrm{CaO}, \mathrm{MgO}, \mathrm{Na}_{2} \mathrm{O}, \mathrm{K}_{2} \mathrm{O}$, $\mathrm{TiO}_{2}, \mathrm{P}_{2} \mathrm{O}_{5}$, and small amounts of $\mathrm{MnO}, \mathrm{BaO}$, and $\mathrm{SO}_{3}$. The detailed chemical composition of fly ash is given in Table 2. The chemical composition of FA may differ based on geographical origin and 
combustion conditions. Some heavy metals are also found in $\mathrm{FA}$, such as $\mathrm{Fe}, \mathrm{Ca}, \mathrm{Zn}, \mathrm{Cd}, \mathrm{Co}, \mathrm{Ni}, \mathrm{Cu}$, $\mathrm{Pb}$ and $\mathrm{Mn}$ [71], as shown in Table 3. FA can also be divided into high calcium ash $(\geq 10 \% \mathrm{CaO})$ and low calcium ash $(<10 \% \mathrm{CaO})$, according to the content of $\mathrm{CaO}$. High calcium ash can remove acidic gases and fix hazardous heavy metals, such as $\mathrm{Cd}$ and $\mathrm{Cu}$. $\mathrm{CaO}$ is present in FA as free lime and embedded in glassy spheres. Usually, the $\mathrm{CaO}$ content increases with decreasing particle size [57]. Loss on ignition (LOI) has long served as a standard method to measure unburned carbon in FA [72,73]. All types of FA have a certain LOI value indicating their unburnt carbon content (Table 2). Unburnt carbon in FA powder has properties similar to activated carbon, such as good adsorption capacity.

Table 2. Primary chemical compositions for fly ash produced from different coal types (adapted with permission from [5], Elsevier, 2017).

\begin{tabular}{cccc}
\hline Component (wt.\%) & Bituminous & Sub-Bituminous & Lignite \\
\hline $\mathrm{SiO}_{2}$ & $20-60$ & $40-60$ & $15-45$ \\
$\mathrm{Al}_{2} \mathrm{O}_{3}$ & $5-35$ & $20-30$ & $10-25$ \\
$\mathrm{Fe}_{2} \mathrm{O}_{3}$ & $10-40$ & $4-10$ & $4-15$ \\
$\mathrm{CaO}$ & $1-12$ & $5-30$ & $15-40$ \\
$\mathrm{MgO}$ & $0-5$ & $1-6$ & $3-10$ \\
$\mathrm{SO}_{3}$ & $0-4$ & $0-2$ & $0-10$ \\
$\mathrm{Na}_{2} \mathrm{O}$ & $0-4$ & $0-2$ & $0-6$ \\
$\mathrm{~K}_{2} \mathrm{O}$ & $0-3$ & $0-4$ & $0-4$ \\
$\mathrm{LOI}^{\text {a }}$ & $0-15$ & $0-3$ & $0-5$ \\
\hline
\end{tabular}

${ }^{\mathrm{a}}$ LOI, Loss on ignition.

Table 3. The concentration of heavy metals in Yenikoy Toxicity Characteristic Leaching Procedure (TCLP) leachates (adapted with permission from [71], Elsevier, 2018).

\begin{tabular}{ccccccccc}
\hline Heavy Metals & Unit & Fly ash 1 & Fly ash 2 & Fly ash 3 & Fly ash $\mathbf{4}$ & Fly ash 5 & Fly ash $\mathbf{6}$ & Fly ash 7 \\
\hline $\mathrm{Fe}$ & $\mathrm{mg} / \mathrm{kg}$ & 4.2 & 3.2 & 4 & 2.8 & 4 & 4.6 & 3.4 \\
$\mathrm{Ca}$ & $\mathrm{mg} / \mathrm{kg}$ & 67,040 & 55,360 & 58,400 & 48,320 & 78,720 & 85,120 & 74,880 \\
$\mathrm{Zn}$ & $\mathrm{mg} / \mathrm{kg}$ & 2 & 1.6 & 1.8 & 1.6 & 2 & 2 & 2 \\
$\mathrm{Cd}$ & $\mathrm{mg} / \mathrm{kg}$ & 2.8 & 2.2 & 2.4 & 2 & 2.8 & 2.8 & 3 \\
$\mathrm{Co}$ & $\mathrm{mg} / \mathrm{kg}$ & 3.2 & 2.8 & 2.2 & 2 & 2 & 2.6 & 2.4 \\
$\mathrm{Ni}$ & $\mathrm{mg} / \mathrm{kg}$ & 4 & 3.6 & 4.8 & 4 & 3.4 & 3.4 & 5.6 \\
$\mathrm{Cu}$ & $\mathrm{mg} / \mathrm{kg}$ & 2.8 & 2.6 & 2.6 & 2.6 & 3.2 & 3.2 & 3.4 \\
$\mathrm{~Pb}$ & $\mathrm{mg} / \mathrm{kg}$ & 11 & 10 & 11 & 10.4 & 14.2 & 15 & 14.4 \\
$\mathrm{Mn}$ & $\mathrm{mg} / \mathrm{kg}$ & 1.8 & 1.6 & 1.6 & 1.4 & 1.6 & 1.6 & 1.8 \\
\hline
\end{tabular}

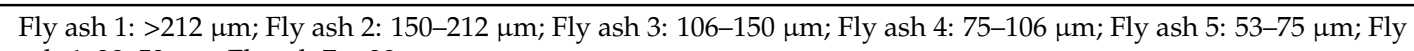
ash 6: 38-53 $\mu \mathrm{m}$; Fly ash 7: $<38 \mu \mathrm{m}$.

Some minerals in FA can be measured by X-ray diffraction (XRD) spectroscopy techniques. Nyambura et al. [57] analyzed the XRD spectra of non-carbonated and carbonated FA, as shown in Figure 9. Minerals in non-carbonated FA were found to mainly consist of amorphous, $\mathrm{CaO}$, hematite, mullite, and quartz (see Figure 9a). The minerals in carbonated FA are mainly composed of amorphous $\mathrm{CaCO}_{3}$, magnetite, mullite, plagioclase, quartz, bassanite, and anhydrite (see Figure 9a). The major crystalline phases are mullite and quartz for most ash [74-77]. The $\mathrm{CaO}$ in non-carbonated FA is converted into calcite (main component: $\mathrm{CaCO}_{3}$ ) when it is carbonized. These results have been described in SEM spectrum analysis, and the "cubic-like" structures in Figure 7c are calcites [57]. Many other researchers have also confirmed these results [78]. Among the many oxides in FA, recovery of alumina has attracted interest in recent decades. Therefore, as science and technology progresses, the recovery and utilization of industrial waste to benefit humans and the environment will help reduce environmental impacts. 


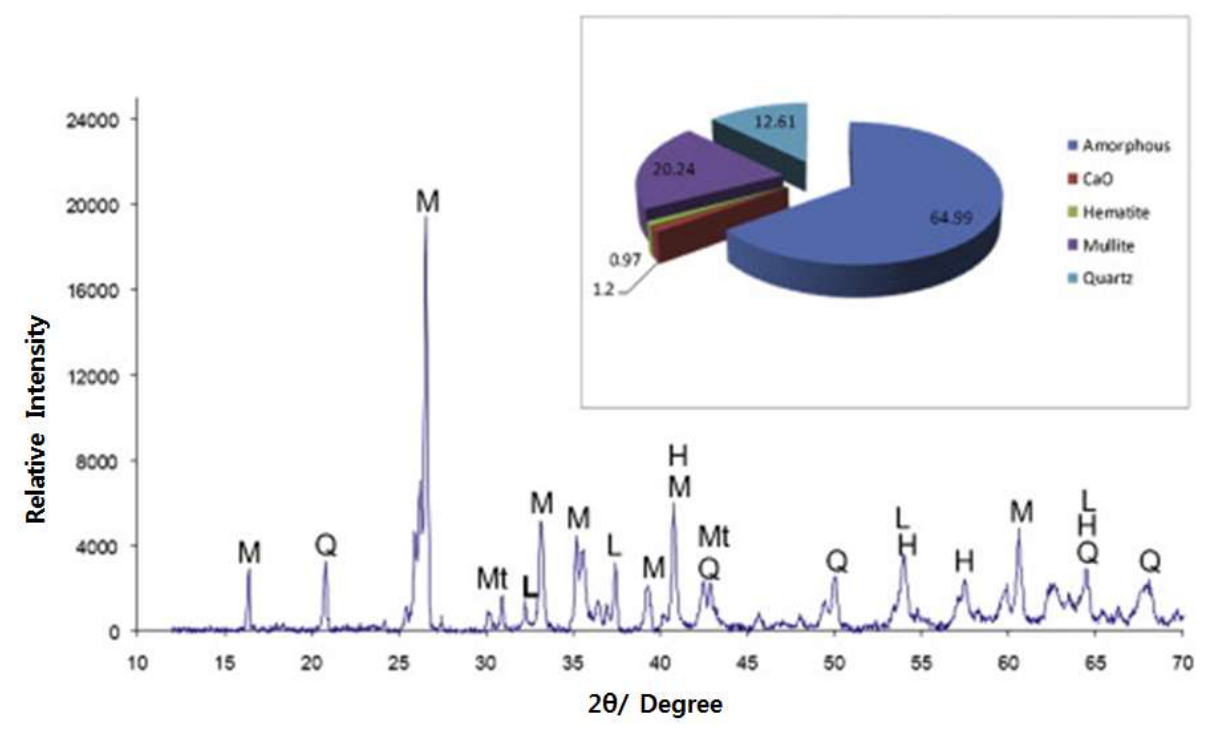

(a)

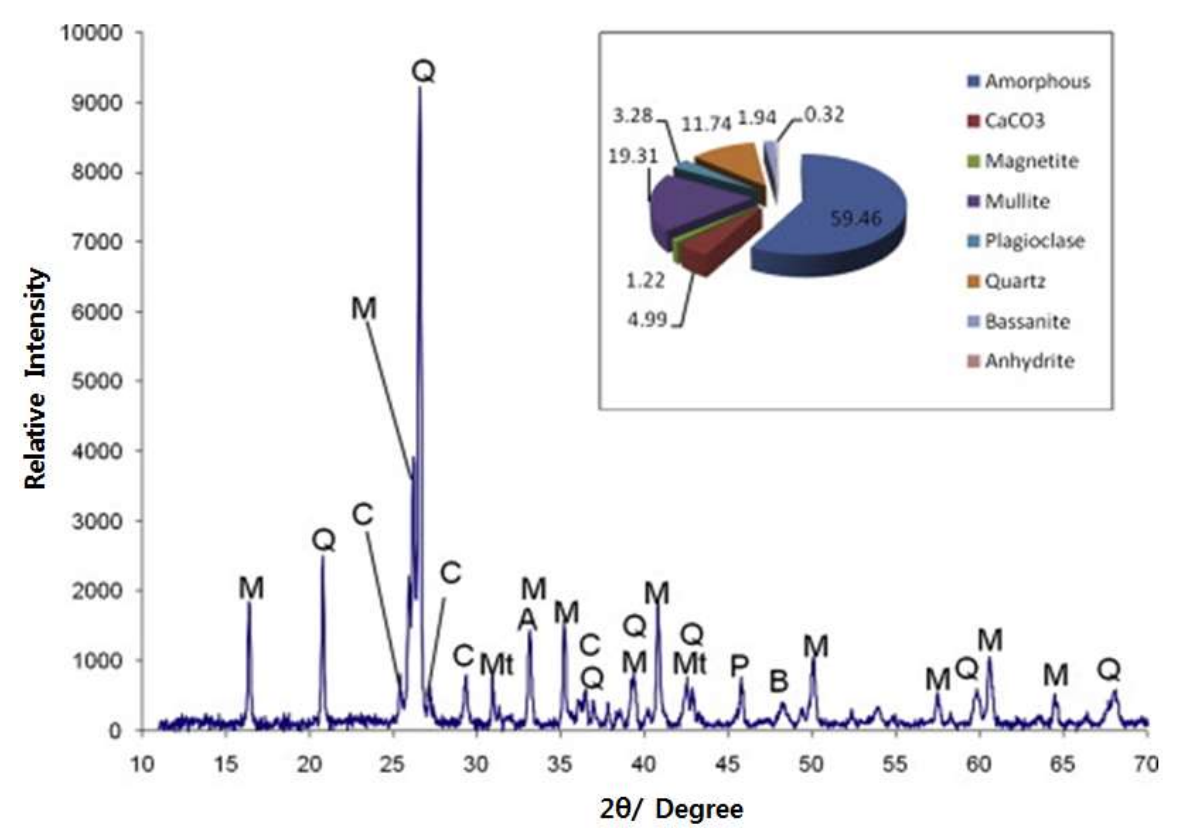

(b)

Figure 9. XRD patterns of: non-carbonated FA (a) and carbonated FA (b). M, mullite; Q, quartz; C, calcite; A, anhydrite; $\mathrm{P}$, plagioclase; $\mathrm{B}$, bassanite; Mt, magnetite; L, lime; and $\mathrm{H}$, hematite (reproduced with permission from [57], Elsevier, 2018).

\section{Application of Fly Ash for Treatment of Pollutants}

\subsection{Removing Air Pollutants}

As a cheap adsorbent, FA can effectively reduce environmental pollution through simple processing due to its high porosity, high surface area, appropriate pore size, high porosity, and other characteristics (e.g., unburned carbon remaining in the fly ash particles and $\mathrm{CaO}$ percentage) [79]. Higher surface area and carbon content having high micropore volume results in a higher adsorption capacity and larger breakthrough time. In addition, the adsorption effect is not only related to the physicochemical properties of the adsorbent itself but also to the physicochemical properties of the adsorbate, such as pore structure, surface functional groups [80]. The air pollutants that can be 
adsorbed by FA include volatile organic compounds (VOCs), nitrogen oxides (NOx) and sulfur dioxide $\left(\mathrm{SO}_{2}\right)$.

\subsubsection{Removal of Volatile Organic Compounds}

Volatile organic compounds (VOCs) are one of air pollutants mainly produced by fossil fuel combustion [81,82], painting [83], refining [84], building [85], and other industries [86,87]. In recent decades, rapid development of industry has led to a dramatic increase in anthropogenic VOCs. There are more than 300 chemical structures of VOCs, which can be classified as alkanes, aromatics, esters, and aldehydes, among others $[88,89]$. Many VOCs are harmful to humans in even small amounts, such as benzenes and formaldehyde, which are suspected carcinogens [90]. Xylene and aliphatic hydrocarbons are mainly produced by the paint industry and are harmful to the environment and humans [91,92]. In sunlight, photochemical reactions of VOCs and NOx will generate ozone, peroxide, nitro-aldehydes, and other photochemical smog compounds that cause secondary pollution and affect people's eyes and respiratory systems, endangering human health [93-96]. Table 4 shows some VOCs harmful to human health [97]. Thus, the reduction and control of VOCs from air are important research topics for air purification.

Table 4. Sources and health effects of major volatile organic compounds (adapted with permission from [97], Elsevier, 2018).

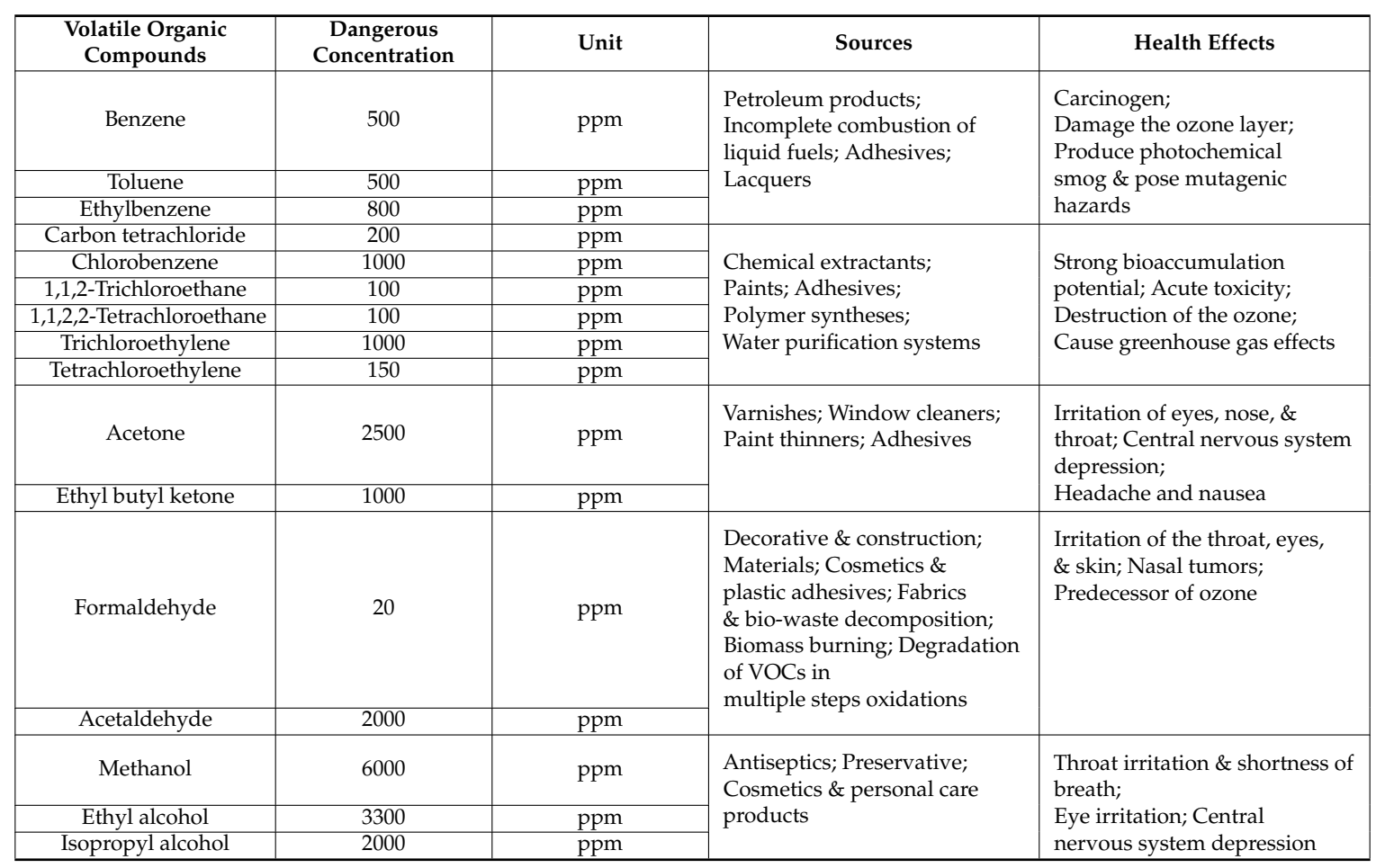

Seo et al. [98] evaluated adsorption capacity of seven building materials (activated carbon, gypsum board mixed with a given quantity of activated carbon, board made out of activated carbon, humidity-controlling porous ceramic material, humidity-controlling silicate calcium, ceramic tile and ordinary gypsum board) for adsorption of four kinds of VOCs in a small test chamber. They showed that activated carbon has the highest VOCs adsorption capacity compared with other building materials. Chmielewski et al. [99] studied the reduction of VOCs from coal combustion using electron beam treatment and found that the concentration of polycyclic aromatic hydrocarbons (VOCs) was greatly reduced from $40 \%$ to $98 \%$. Other researchers have also found that other materials effectively reduce VOCs, including cashew nut shell liquid [100,101], sol-gel [102], CuO-CeO ${ }_{2}$ mixed oxides [103], Mn-Cu mixed oxide [104], manganese oxides [105], and other metal oxide catalysts and 
noble metals [106,107]. Among them, activated carbon is one of the most common adsorbents because of its low-cost, high availability, excellent specific surface area, pore size, porosity, chemical functional group, and other properties [108-110]. Nevertheless, activated carbon adsorption of macromolecules and hydrophilic VOCs is not good because it has a multi-microporous structure and is a nonpolar adsorbent [97]. On the other hand, activated carbon fibers adsorb VOCs better than activated carbon because of their short and straight thin-fiber shaped micropores that increase intraparticle adsorption kinetics compared to activated carbon [111,112]. In addition, activated carbon fibers also play an important role during adsorption or desorption, have large adsorption capacity and have high mass transfer rates $[113,114]$.

Similar to adsorption on activated carbon fibers, FA can be used to fabricate a functional adsorption fibrous membrane through simple electrospinning [32]. Electrospinning is an efficient method for fabricating fibers from nanometer to micrometer, with advantages of high efficiency, low cost, and easy operation [115]. Figure 10 shows a schematic of an electrospun fibrous membrane and a VOCs adsorption experiment. The spinnable functional material (e.g., fly ash) and polymer (e.g., polyacrylonitrile (PAN), polyurethane (PU), and Polylactic acid (PLA)) are mixed with the chemical solvent (e.g., N,N dimethylformamide (DMF) and methyl ethyl ketone (MEK)) at a certain ratio, then as-prepared spinning solution is further processed using magnetic stirring and ultrasonication to obtain a homogenous spinning solution, and finally the composite membrane is collected on the roller under the action of the electrostatic field. The size and arrangement of electrospun fibers are affected by viscosity, conductivity and feed rate of spinning solution, distance between nozzle and collector, supply voltage, etc. [88,116]. Kim et al. [33] successfully synthesized polyurethane fibers containing different amounts of FA and analyzed their adsorption of chloroform, benzene, toluene, xylene, and styrene (Figure 11). They found that polyurethane fibers containing $30 \mathrm{wt} \%$ FA had the smallest fiber diameter and the maximum specific surface area, it results in the highest VOCs adsorption capacity compared to other fibrous membranes. Furthermore, the adsorption of VOCs by fibrous membranes was in the following order: styrene $>$ xylene $>$ toluene $>$ benzene $>$ chloroform. This is because adsorption of VOCs not only depends on the surface area and fiber diameter, but also on other characteristics, including molecular polarity, molecular structure, molecular weight, pore size, porosity, chemical functional groups electronic and steric effects, $\pi$-complexes, adsorption kinetics, ionization potential, dipole moment, boiling point, temperature and humidity $[97,117,118]$. In general, lower ionization potential aromatic compounds are easier to be absorbed by FA fibrous membranes due to their instability [32]. The adsorbent with high $\mathrm{C} / \mathrm{O}$ ratio has the high adsorption capacity for adsorption of nonpolar VOCs [119]. Use of FA fibrous membrane to adsorb VOCs from air is an innovative research, which provides a new idea for using FA fibrous membrane to filter air pollutants. As an emerging material, FA fibrous membrane can be modified into a variety of air filters with great development potential in the field of environmental pollution management [32,33]. 


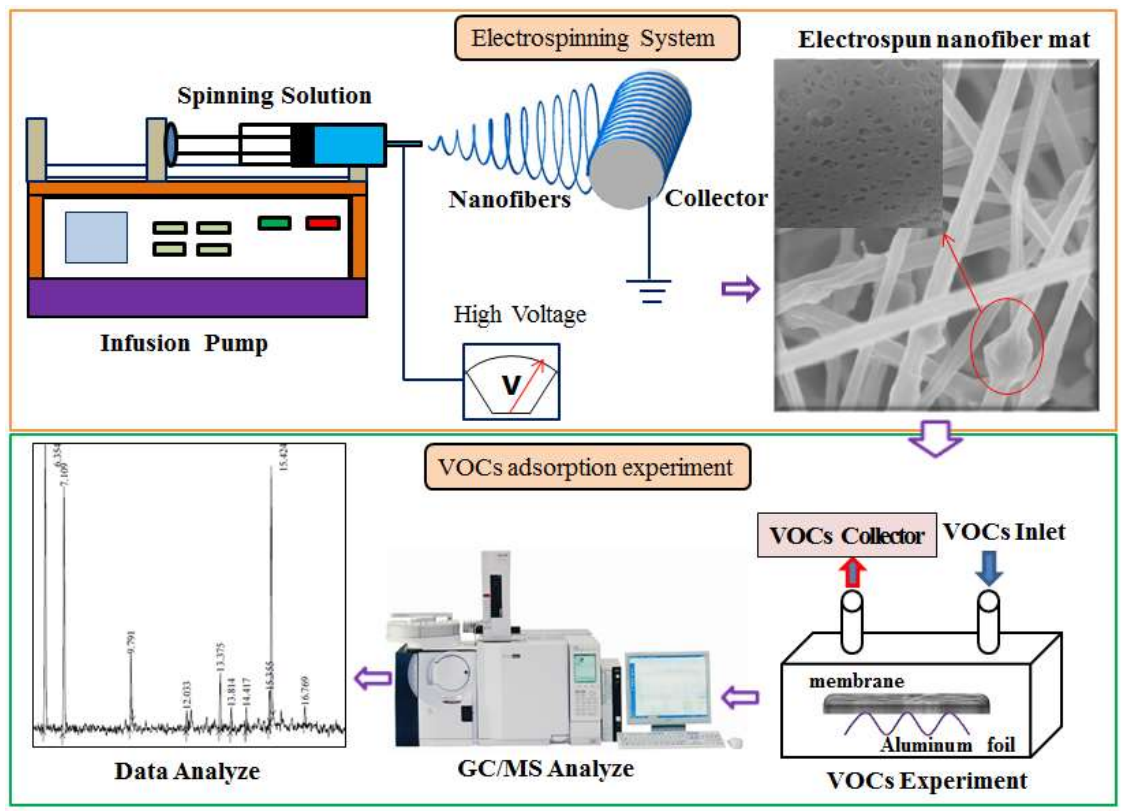

Figure 10. Schematic diagram of electrospun fibrous membrane and VOCs adsorption experiment.
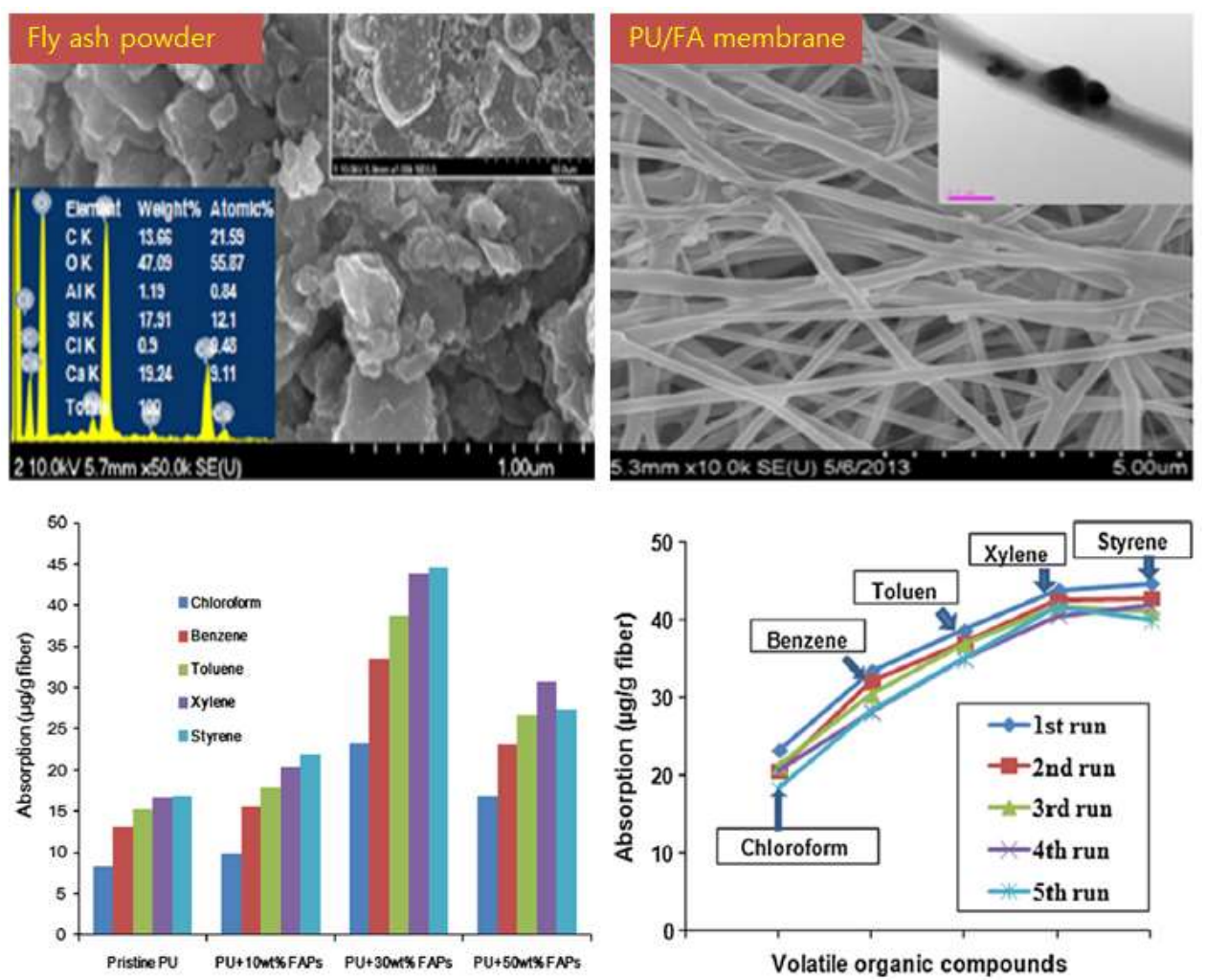

Figure 11. SEM images and VOCs adsorption capacity of FA membranes (adapted with permission from [33], Elsevier, 2018).

\subsubsection{Removal of Nitrogen Oxides}

A small amount of NOx can be adsorbed by FA because of the unburned carbon in FA and the physical characteristics of FA such as high porosity and specific surface area [120]. In fact, this carbon is a precursor to activated carbon, but it has gone through devolatilization during combustion in the furnace of a power station [121]. Therefore, the internal carbon can be activated by some simple 
modifications to the FA to increase its adsorption capacity. The general method used is steam activation and physical separation, but, because the ash content of carbon-enriched FA is too high, using chemical demineralization to activate carbon is the best method [122]. Rubio et al. [122] studied adsorption of NOx by unburnt carbon from FA and found that the conversion curves of NO on different FA samples reached steady state after $10 \mathrm{~h}$. In addition, the enriched-carbon FA showed high NO abatement capacity due to increased carbon content, surface area, and porosity. Izquierdo et al. [30] synthesized $\mathrm{Cu}$ and Fe exchange type Y zeolites from FA for removal of NOx from flue gas. Rubel et al. [123] also reported that carbon-rich products from combustion ash could decrease NOx emissions and $\mathrm{Hg}$ due to ion-pair interactions between $\mathrm{NO}^{+}$and $\mathrm{O}_{2}{ }^{-}$at the surface of carbon, with subsequent condensation of $\mathrm{NO}_{2}$ in micropores. In addition, the pore size on the surface of the adsorbent can be changed after adsorption of a certain amount of $\mathrm{Hg}$, producing the optimum pore size (micropores, $<2 \mathrm{~nm}$ ) for adsorbed NOx [124]. Rubel et al. [123] also showed that the surface area of adsorbents increased due to adsorption of NOx, as shown in Figure 12. From the above literature, it can be concluded that unburned carbon concentration in FA plays a decisive role for reducing NOx from air, and the high surface area of FA will further improve the NOx adsorption capacity. In addition, the unburned carbon remaining in the FA particles contribute the main surface area to FA, and the carbon can be activated to further improve the adsorption performance of the FA [5].

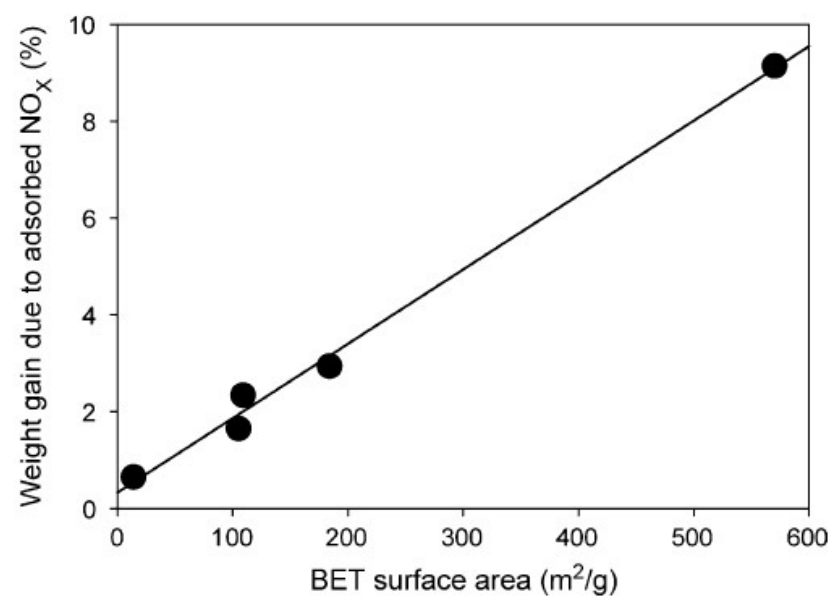

Figure 12. Relationship between BET surface area of adsorbent and adsorbed NOx (reproduced with permission from [123], Elsevier, 2018).

\subsubsection{Removal of Sulfur Dioxide}

Coal power generation plays an important role in electricity generation worldwide, accounting for about $41 \%$ of the world's power generation in 2006. In some countries, this percentage is even higher, such as Poland $(92 \%)$, China $(79 \%)$, and India $(69 \%)[125,126]$. The large amount of coal used causes an increase in $\mathrm{SO}_{2}$ and a small amount of $\mathrm{SO}_{3}$, which pollute the air. $\mathrm{SO}_{2}$ is the main chemical responsible for formation of acid rain [127-129]. In addition, $\mathrm{SO}_{2}$ and $\mathrm{SO}_{3}$ are harmful gases that contribute to formation of submicron acid particles that can penetrate human lungs and be absorbed into the bloodstream [130]. Many researchers have reported that blending FA with $\mathrm{Ca}(\mathrm{OH})_{2}$ or $\mathrm{CaO}$ can produce an adsorbent via a hydration process with a better $\mathrm{SO}_{2}$ reduction than that of hydrated lime [131-133]. Lee et al. [134] found similar results, as shown in Figure 13. An adsorbent composed of a mixture of $\mathrm{FA} / \mathrm{CaO} / \mathrm{CaSO}_{4}$ was successfully synthesized with a higher $\mathrm{SO}_{2}$ adsorption capacity than that of pure $\mathrm{FA}, \mathrm{CaSO}_{4}$, and $\mathrm{CaO}$, due to its larger specific surface area $\left(64.5 \mathrm{~m}^{2} / \mathrm{g}\right)$. In addition, no adsorbents exhibited significant desulfurization activity. SEM images of adsorbent before and after $\mathrm{SO}_{2}$ adsorption are shown in Figure 14. The high density of pore structures on the surface of the adsorbent before adsorbing $\mathrm{SO}_{2}$ can be clearly seen. However, the pores disappear after adsorption of $\mathrm{SO}_{2}$, due to $\mathrm{SO}_{2}$ being converted into sulfate salts $\left(\mathrm{CaSO}_{4}\right)$ and covering the surface of the adsorbent. 
From the above results, it can be concluded that the ability of $\mathrm{FA}$ to capture $\mathrm{SO}_{2}$ is mainly related to its surface area, pore structures and calcium ion content. Specific surface area is increased after the FA is hydrated, leading to more calcium ions that can react with $\mathrm{SO}_{2}$ to produce $\mathrm{CaSO}_{4}[135,136]$.

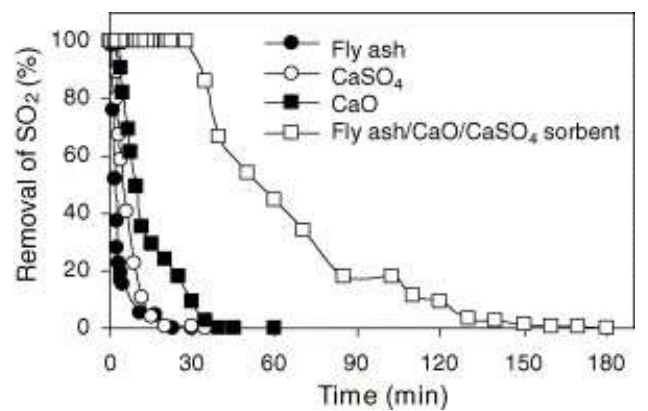

(a)

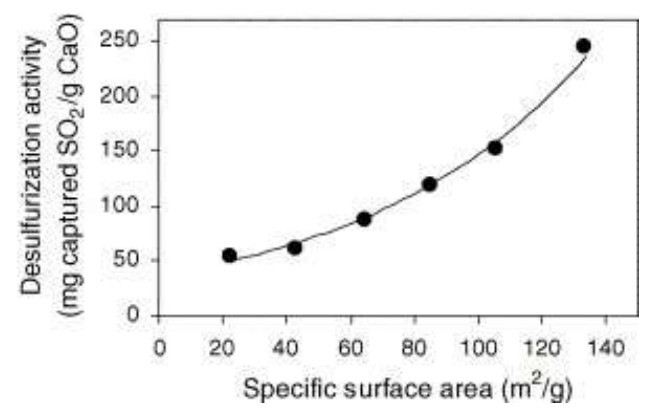

(b)

Figure 13. (a) Desulfurization activity of different adsorbents; and (b) relationship between desulfurization capacity and specific surface area (reproduced with permission from [134], Elsevier, 2018).
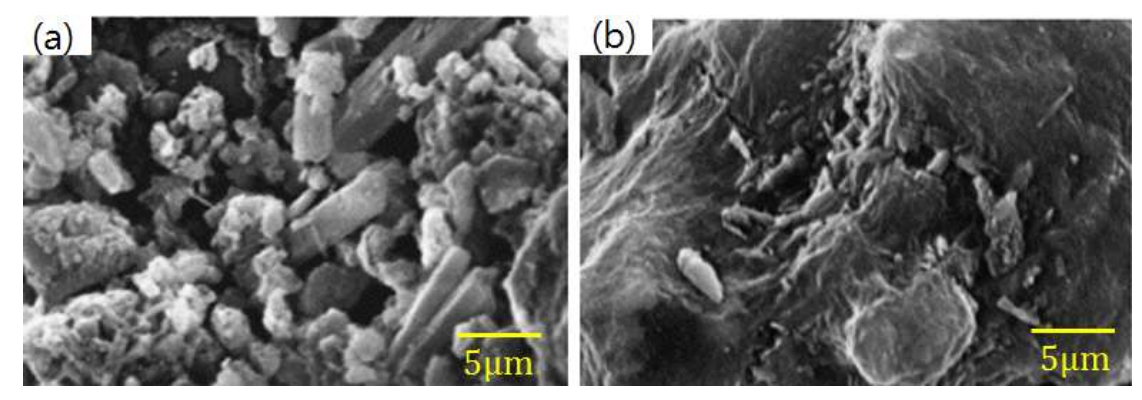

Figure 14. Comparison of SEM images before (a) and after $(\mathbf{b}) \mathrm{SO}_{2}$ adsorption (adapted with permission from [134], Elsevier, 2018).

\subsection{Removing Water Pollutants}

\subsubsection{Removal of Heavy Metals}

Industrial development is likely to cause water pollution, especially heavy metal pollution, because of its inherent toxicity, large sources, persistence, non-degradability, and other factors and can cause serious harm to humans, animals, plants, and the environment $[137,138]$. Some of the common sources of anthropogenic heavy metals are displayed in Table 5. The treatment of waste water containing heavy metal can be divided into three categories: physical methods, chemical methods, and biological methods $[5,139]$. Physical methods include adsorption (activated carbon, carbon nanotubes, kaolinite and montmorillonite, FA, and other low-cost adsorbents), membrane filtration (ultrafiltration, reverse osmosis, nanofiltration, and electrodialysis), coagulation and flocculation, flotation, and other methods $[5,140]$. Chemical methods include chemical precipitation (hydroxide precipitation, sulfide precipitation, chelating precipitation, and chemical precipitation combined with other methods), ion-exchange, electrochemical treatment technologies, and others $[5,139]$. Biological methods include bio-adsorbents and use of microorganism, as well as others [141,142]. Among them, ion-exchange, adsorption and membrane filtration are the most commonly used method, and use of modified FA is an economical and efficient method for treatment of heavy metal wastewater because FA is derived from industrial waste. 
Table 5. Primary sources of common heavy metals and their effects on human organs (reproduced with permission from [143], Elsevier, 2017).

\begin{tabular}{|c|l|l|l|}
\hline Metal & \multicolumn{1}{|c|}{ Target Organs } & \multicolumn{1}{c|}{ Primary Sources } & \multicolumn{1}{c|}{ Clinical Effects } \\
\hline $\mathrm{As}$ & $\begin{array}{l}\text { Pulmonary nervous } \\
\text { system, skin }\end{array}$ & $\begin{array}{l}\text { Industrial dusts, } \\
\text { medicinal uses of } \\
\text { polluted water }\end{array}$ & $\begin{array}{l}\text { Perforation of nasal } \\
\text { septum, respiratory } \\
\text { cancer, peripheral } \\
\text { neuropathy: } \\
\text { dermatomes, skin cancer }\end{array}$ \\
\hline $\mathrm{Cd}$ & $\begin{array}{l}\text { Renal, skeletal, } \\
\text { pulmonary }\end{array}$ & $\begin{array}{l}\text { Industrial dust and } \\
\text { fumes and polluted } \\
\text { water and food }\end{array}$ & $\begin{array}{l}\text { Proteinuria, glucosuria, } \\
\text { osteomalacia, } \\
\text { aminoaciduria, } \\
\text { emphysema }\end{array}$ \\
\hline $\mathrm{Cr}$ & Pulmonary & $\begin{array}{l}\text { Industrial dust and } \\
\text { fumes and polluted food }\end{array}$ & $\begin{array}{l}\text { Ulcer, perforation of } \\
\text { nasal septum, respiratory } \\
\text { cancer }\end{array}$ \\
\hline $\mathrm{Mn}$ & Nervous system & $\begin{array}{l}\text { Industrial dust and } \\
\text { fumes }\end{array}$ & $\begin{array}{l}\text { Central and peripheral } \\
\text { neuropathies }\end{array}$ \\
\hline $\mathrm{Pb}$ & $\begin{array}{l}\text { Nervous system, } \\
\text { hematopoietic system, } \\
\text { renal }\end{array}$ & $\begin{array}{l}\text { Industrial dust and } \\
\text { fumes and polluted food }\end{array}$ & $\begin{array}{l}\text { Encephalopathy, } \\
\text { peripheral neuropathy, } \\
\text { central nervous } \\
\text { disorders, anemia }\end{array}$ \\
\hline $\mathrm{Ni}$ & Pulmonary, skin & Industrial dust, aerosols & Cancer, dramatis \\
\hline $\mathrm{Sn}$ & Nervous system, & $\begin{array}{l}\text { Medicinal uses, } \\
\text { industrial dusts }\end{array}$ & $\begin{array}{l}\text { Central nervous system } \\
\text { disorders, visual defects } \\
\text { and EEG changes, } \\
\text { pneumoconiosis }\end{array}$ \\
\hline $\mathrm{Hg}$ & Nervous system, renal & $\begin{array}{l}\text { Industrial dust and } \\
\text { fumes and polluted } \\
\text { water and food }\end{array}$ & Proteinuria \\
\hline
\end{tabular}

FA can be used directly or indirectly (synthesized as zeolites) to adsorb heavy metal from polluted water [144-146]. It is a potential adsorbent that can remove $\mathrm{Cu}, \mathrm{Pb}, \mathrm{Zn}, \mathrm{Mn}, \mathrm{Cd}, \mathrm{Cr}$, and $\mathrm{Ni}$ from wastewater $[147,148]$. On the other hand, the $\mathrm{pH}$ of the aqueous solution directly affects adsorption of metal ions due to changes in surface charge of the adsorbent and the degree of ionization $[26,144]$. FA has a high adsorption capacity for $\mathrm{Cu}^{2+}$ and $\mathrm{Zn}^{2+}$ ions at $\mathrm{pH}$ 8. In addition, using FA to adsorb $\mathrm{Cu}^{2+}$ and $\mathrm{Zn}^{2+}$ ions was faster than that of natural zeolite and peanut husk [149]. The SEM images of the FA before and after the adsorption of heavy metals are shown in Figure 15. As shown in Figure 15b, the porosity between the FA particles is significantly reduced. This could be attributed to that the surface of FA is covered by complexes formed by heavy metal ions [26]. Moreover, FA has a stronger adsorption capacity for $\mathrm{Pb}^{2+}$ and $\mathrm{Cd}^{2+}$ than other heavy metal ions. Adsorption of $\mathrm{Pb}^{2+}$ and $\mathrm{Cd}^{2+}$ can be attributed to chemical sorption or chemisorption involving valence forces through sharing or exchange of electrons between the sorbent and sorbate, because their adsorption kinetics followed second-order reaction kinetics $[26,150]$. With the development of nanotechnology, FA can be fabricated into a functional fibrous membrane with a high capacity for adsorbing heavy metals [34]. FA particles can be perfectly combined with polyurethane fibers via electrospinning, and the FA fibrous membrane has higher adsorption capacity and faster adsorption rate for adsorption of $\mathrm{Pb}$ than that of $\mathrm{Hg}$. This is attributed to the affinity of formation of $\mathrm{PbOH}^{+}$being higher than to $\mathrm{HgOH}^{+}$[34]. The results are encouraging for the removal of heavy metals using FA fibrous membrane from industrial wastewater. FA fibrous membrane can be used as a variety of filters with low-cost and high performance. These are a great help to improve the utilization of FA and reduce the pressure of environmental pollution. The mechanism of modified FA for treatment of heavy metal wastewater can be summarized as follows: most FA is alkaline with a high adsorption capacity and high surface area, and negative charge accumulates at the FA surface in alkaline solutions. FA can be expected to remove some metal ions from wastewater by electrostatic interactions or precipitation-adsorption. The ion exchange capacity, high surface area, and unique pore characteristics of modified FA play an important role for treatment of heavy metal wastewater $[15,139]$. 

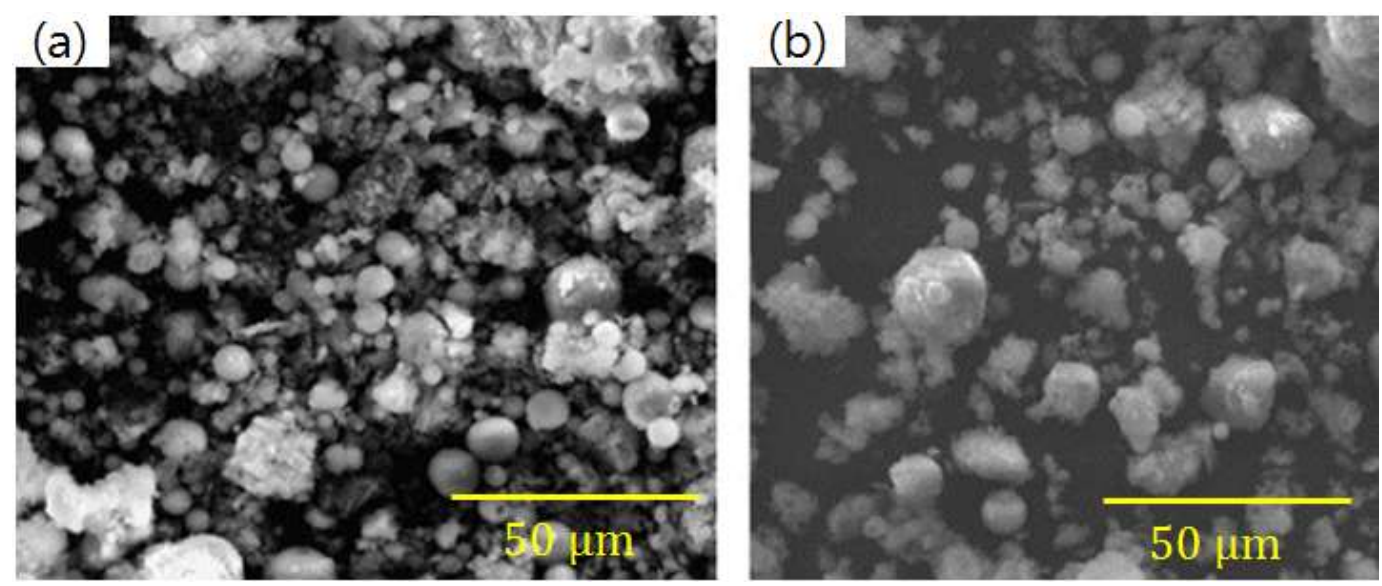

Figure 15. Comparison of SEM images before (a) and after (b) heavy metal adsorption (adapted with permission from [26], Elsevier, 2018).

\subsubsection{Removal of Other Organic/Inorganic Components}

On the other hand, FA not only has the capacity to adsorb heavy metals from wastewater, but also has the ability to adsorb other organic/inorganic pollutants from wastewater, including to phosphorous, fluoride, boron, phenolic compounds, pesticides, dyes, etc. [5,151]. Phosphorus is an indispensable element in living organisms. Phosphorus is required for the metabolism of organisms. Therefore, when the phosphorus chemical industry discharges phosphorus compounds into rivers, it will lead to the "eutrophication" of water, which will lead to the rapid growth of algae and other plants, and absorb a large amount of free oxygen in the water, posing a great threat to the ecological environment. Many researchers [152,153] have studied the use of FA to remove phosphorus from wastewater. Kandel et al. reported that mixture of sand with $5 \%$ of FA by weight can effectively reduce phosphorus concentration in water [151]. They showed that the FA has a good effect of adsorb or precipitate phosphate because of the FA contains a certain amount of calcium contents. The removal efficiency of phosphate is affected by $\mathrm{pH}$ conditions and calcium content in FA. In general, alkaline conditions for high-calcium FA, neutral $\mathrm{pH}$ levels for medium-calcium FA have a high ability to remove phosphate, and the low-calcium FA immobilized little phosphate at all $\mathrm{pH}$ values [154]. In addition, the iron contained in FA can also react with phosphate to cause phosphate to be precipitated. Using FA to remove phosphorus from wastewater is primarily due to the precipitation of phosphate with $\mathrm{Ca}^{2+}$ ions in solution, and the weak physical interactions between the surface of FA and the phosphate [155]. Xu et al. [156] found that a magnesia-loaded fly ash cenospheres (MLC) is an efficient adsorbent for adsorption of fluoride. The influence of temperature, initial fluoride concentration, $\mathrm{pH}$ of the solution, contact time, coexisting ions, and fly ash dosage on fluoride removal was respectively investigated. They indicated that when the $\mathrm{pH}$ of the solution is 3, MLC has the maximum adsorption of fluorine, which is mainly due to highly protonated MLC surface and the gradual increase in the attractive forces between the positively charged surface and the negatively charged fluoride ions. Polat et al. [70] investigated the removal of boron from seawater and desalinated seawater on FA. They carried out several series of column and batch experiments and determined that there is a significant reduction of boron concentration in seawater after interaction with FA. Under suitable conditions (e.g., $\mathrm{pH}=9, \mathrm{~L} / \mathrm{S}$ $=1 / 10$, reaction time $>6 \mathrm{~h}$ ), more than $95 \%$ of boron was removed by FA. Phenolic compounds are one of the major pollutants in polluted water. Phenol will volatilize into the atmosphere or infiltrate underground, polluting the atmosphere, groundwater and crops when untreated phenolic wastewater is used to irrigate crops. Phenol, cresol and other volatile phenols have attracted wide attention. FA as a waste material can be used as adsorbents for the removal of phenolic compounds. Ahmaruzzaman et al. [157] and Kao et al. [158] reported that the high adsorption capacity of FA was related to its high-surface-area, pore volume, porosity and higher unburned carbon content. Moreover, phenols 
have a strong hydroxyl functional group which interacts with the adsorbent surfaces, resulting in vertical alignment of the molecule on the surface. Therefore, phenol can be more adsorbed by FA because of the interaction between adsorbed molecules. Other researchers [159,160] have demonstrated that FA also has the ability to remove pesticides, various dyes and pigments from wastewater. FA is low cost and more effective for adsorption of multiple harmful substances to be used widely in wastewater treatment.

\section{Conclusions}

Fly ash (FA) can be used as the base material of some adsorbents to treat air and water pollution due to its high porosity, high surface area, appropriate pore size, $\mathrm{CaO}$ percentage and surface functional groups. It can be fabricated into a variety of composite materials including zeolites and fiber membranes. They have excellent adsorption capacity in controlling air and water pollutants, such as VOCs, SOx, NOx, heavy metals and toxic organic dyes. In this paper, the mechanism of FA for adsorption of air pollutants and water pollutants has been studied, in addition to a comparison of FA production of different countries, as well as the physical and chemical properties of FA. Detailed results are as follows:

1. Fly ash can be used in building materials, building works, roads construction, agriculture, and other fields.

2. To improve the adsorption capacity and efficiency of fly ash on environmental pollutants and make full use of fly ash, new technologies for the efficient utilization of fly ash should be developed, such as nanofiber technology.

3. Fly ash can be converted to inexpensive and high performance adsorbents by simple modifications due to its unique porous properties. For example, is can be made into various kinds of zeolites.

4. Modified fly ash can adsorb VOCs, $\mathrm{NOx}$ and $\mathrm{SO}_{2}$ emissions in the air and can also remove some heavy metals and other organic/inorganic pollutants (e.g., phosphorous, fluoride, boron, phenolic compounds, pesticides and dyes) from wastewater, due to its high porosity, high surface area, appropriate pore size, high porosity, alkalinity, negative charge, unburned carbon remaining in the fly ash particles and other unique characteristics.

5. In addition, the adsorption effect is not only related to the physicochemical properties of the adsorbent itself but also to the physicochemical properties of the adsorbate, e.g., polar/non-polar, and functional groups.

6. Pristine fly ash is a powder, which limits its scope of use. Using nanotechnology, it can be synthesized into low-cost, multi-functional and multi-purpose porous hybrid composites for adsorption of air pollutants and water pollutants. Fly ash porous hybrid composites as an emerging material, which has great potential in the future.

Author Contributions: J.C.G. made suggestions, analyzed the physicochemical properties of fly ash, summarized the adsorption mechanism of the fly ash composite materials for treatment of environmental pollutants, and drafted this manuscript. S.K.Y. summarized and analyzed the production and consumption of fly ash from several representative countries, summarized the synthetic methods of the fly ash composite materials and analyzed their development trend in the future. N.J.C. guided the idea of this manuscript, analyzed the application of the fly ash composite materials in the control of environmental pollutants, and supervised the work and the manuscript. All authors participated in the evaluation of the data, and reading and approving the final manuscript.

Funding: This research was funded by [the Ministry of Education] grant number [2016R1D1A1B03931616].

Acknowledgments: This research was supported by the Basic Science Research Program through the National Research Foundation of Korea (NRF) funded by the Ministry of Education (Project No. 2016R1D1A1B03931616).

Conflicts of Interest: The authors declare no conflict of interest. 


\section{References}

1. Deng, F.; Pan, Y.; Sun, W.; Yang, F.; Zhang, Y.; Huang, Z. An ignition delay time and chemical kinetic study of ethane sensitized by nitrogen dioxide. Fuel 2017, 207, 389-401. [CrossRef]

2. Kampa, M.; Castanas, E. Human health effects of air pollution. Environ. Pollut. 2008, 151, 362-367. [CrossRef] [PubMed]

3. Bernstein, J.A.; Alexis, N.; Barnes, C.; Bernstein, I.L.; Nel, A.; Peden, D.; Diaz-Sanchez, D.; Tarlo, S.M.; Williams, P.B. Health effects of air pollution. J. Allergy Clin. Immunol. 2004, 114, 1116-1123. [CrossRef] [PubMed]

4. Zheng, N.; Liu, J.; Wang, Q.; Liang, Z. Health risk assessment of heavy metal exposure to street dust in the zinc smelting district, northeast of China. Sci. Total Environ. 2010, 408, 726-733. [CrossRef] [PubMed]

5. Ahmaruzzaman, M. A review on the utilization of fly ash. Prog. Energy Combust. Sci. 2010, 36, $327-363$. [CrossRef]

6. Zhao, C.; Luo, K. Household consumption of coal and related sulfur, arsenic, fluorine and mercury emissions in China. Energy Policy 2018, 112, 221-232. [CrossRef]

7. Bartoňová, L. Unburned carbon from coal combustion ash: An overview. Fuel Process. Technol. 2015, 134, $136-158$. [CrossRef]

8. Ding, M.; Han, W.; Li, J.; Ma, E.; Shan, Z. In situ study of the mechanical properties of airborne haze particles. Sci. Chin. Technol. Sci. 2015, 58, 2046-2051. [CrossRef]

9. Chen, S.; Xu, L.; Zhang, Y.; Chen, B.; Wang, X.; Zhang, X.; Zheng, M.; Chen, J.; Wang, W.; Sun, Y. Direct observations of organic aerosols in common wintertime hazes in north China: Insights into direct emissions from chinese residential stoves. Atmos. Chem. Phys. 2017, 17, 1259-1270. [CrossRef]

10. Ge, J.C.; Yoon, S.K.; Choi, N.J. Using canola oil biodiesel as an alternative fuel in diesel engines: A review. Appl. Sci. 2017, 7, 881. [CrossRef]

11. Iyer, R.S.; Scott, J.A. Power station fly ash-A review of value-added utilization outside of the construction industry. Resour. Conserv. Recycl. 2001, 31, 217-228. [CrossRef]

12. Zhuang, X.Y.; Chen, L.; Komarneni, S.; Zhou, C.H.; Tong, D.S.; Yang, H.M.; Yu, W.H.; Wang, H. Fly ash-based geopolymer: Clean production, properties and applications. J. Cleaner Prod. 2016, 125, 253-267. [CrossRef]

13. Park, J.H.; Edraki, M.; Mulligan, D.; Jang, H.S. The application of coal combustion by-products in mine site rehabilitation. J. Clean. Prod. 2014, 84, 761-772. [CrossRef]

14. Lanzerstorfer, C. Fly ash from coal combustion: Dependence of the concentration of various elements on the particle size. Fuel 2018, 228, 263-271. [CrossRef]

15. Yao, Z.; Ji, X.; Sarker, P.; Tang, J.; Ge, L.; Xia, M.; Xi, Y. A comprehensive review on the applications of coal fly ash. Earth Sci. Rev. 2015, 141, 105-121. [CrossRef]

16. Bouzoubaa, N.; Lachemi, M. Self-compacting concrete incorporating high volumes of class F fly ash: Preliminary results. Cem. Concr. Res. 2001, 31, 413-420. [CrossRef]

17. Abbas, S.; Saleem, M.A.; Kazmi, S.M.; Munir, M.J. Production of sustainable clay bricks using waste fly ash: Mechanical and durability properties. J. Build. Eng. 2017, 14, 7-14. [CrossRef]

18. Kumar, S. Fly ash-lime-phosphogypsum hollow blocks for walls and partitions. Build. Environ. 2003, 38, 291-295. [CrossRef]

19. Dilmore, R.M.; Neufeld, R.D. Autoclaved aerated concrete produced with low NOx burner/selective catalytic reduction fly ash. J. Energy Eng. 2001, 127, 37-50. [CrossRef]

20. Kumar, S. A perspective study on fly ash-lime-gypsum bricks and hollow blocks for low cost housing development. Constr. Build. Mater. 2002, 16, 519-525. [CrossRef]

21. Andini, S.; Cioffi, R.; Colangelo, F.; Grieco, T.; Montagnaro, F.; Santoro, L. Coal fly ash as raw material for the manufacture of geopolymer-based products. Waste Manag. 2008, 28, 416-423. [CrossRef] [PubMed]

22. Koukouzas, N.; Ketikidis, C.; Itskos, G.; Spiliotis, X.; Karayannis, V.; Papapolymerou, G. Synthesis of CFB-coal fly ash clay bricks and their characterisation. Waste Biomass Valoriz. 2011, 2, 87-94. [CrossRef]

23. Jala, S.; Goyal, D. Fly ash as a soil ameliorant for improving crop production-A review. Bioresour. Technol. 2006, 97, 1136-1147. [CrossRef] [PubMed]

24. Basu, M.; Pande, M.; Bhadoria, P.; Mahapatra, S. Potential fly-ash utilization in agriculture: A global review. Prog. Nat. Sci. 2009, 19, 1173-1186. [CrossRef] 
25. Ram, L.; Srivastava, N.; Tripathi, R.; Jha, S.; Sinha, A.K.; Singh, G.; Manoharan, V. Management of mine spoil for crop productivity with lignite fly ash and biological amendments. J. Environ. Manag. 2006, 79, $173-187$. [CrossRef] [PubMed]

26. Mohan, S.; Gandhimathi, R. Removal of heavy metal ions from municipal solid waste leachate using coal fly ash as an adsorbent. J. Hazard. Mater. 2009, 169, 351-359. [CrossRef] [PubMed]

27. Bayat, B. Comparative study of adsorption properties of turkish fly ashes: I. The case of nickel (II), copper (II) and zinc (II). J. Hazard. Mater. 2002, 95, 251-273. [CrossRef]

28. Bhattacharyya, A.; Kerketta, S.; Kumar, M.S.; Rajanikanth, B. Discharge Plasma Cascaded with Fly Ash for Removal of NOx in Biodiesel Exhaust: A Feasibility Study. Int. J. Plasma Environ. Sci. Technol. 2014, 8, 98-102.

29. Hower, J.C.; Maroto-Valer, M.M.; Taulbee, D.N.; Sakulpitakphon, T. Mercury capture by distinct fly ash carbon forms. Energy Fuels 2000, 14, 224-226. [CrossRef]

30. Izquierdo, M.; Rubio, B. Carbon-enriched coal fly ash as a precursor of activated carbons for $\mathrm{SO}_{2}$ removal. J. Hazard. Mater. 2008, 155, 199-205. [CrossRef] [PubMed]

31. Zhou, L.; Chen, Y.-L.; Zhang, X.-H.; Tian, F.-M.; Zu, Z.-N. Zeolites developed from mixed alkali modified coal fly ash for adsorption of volatile organic compounds. Mater. Lett. 2014, 119, 140-142. [CrossRef]

32. Kim, H.J.; Pant, H.R.; Choi, N.J.; Kim, C.S. Fly ash/polyurethane thin film for the adsorption of volatile organic compounds (VOCs) from air. Fibers Polym. 2014, 15, 1393-1398. [CrossRef]

33. Kim, H.J.; Pant, H.R.; Choi, N.J.; Kim, C.S. Composite electrospun fly ash/polyurethane fibers for absorption of volatile organic compounds from air. Chem. Eng. J. 2013, 230, 244-250. [CrossRef]

34. Joo Kim, H.; Raj Pant, H.; Hee Kim, J.; Jung Choi, N.; Sang Kim, C. Fabrication of multifunctional TiO $2-f l y$ ash/polyurethane nanocomposite membrane via electrospinning. Ceram. Int. 2014, 40, 3023-3029. [CrossRef]

35. Pant, H.R.; Kim, H.J.; Joshi, M.K.; Pant, B.; Park, C.H.; Kim, J.I.; Hui, K.; Kim, C.S. One-step fabrication of multifunctional composite polyurethane spider-web-like nanofibrous membrane for water purification. J. Hazard. Mater. 2014, 264, 25-33. [CrossRef] [PubMed]

36. Xu, J.; Zhou, M.; Li, H. The drag effect of coal consumption on economic growth in China during 1953-2013. Resour. Conserv. Recycl. 2018, 129, 326-332. [CrossRef]

37. He, Y.; Luo, Q.; Hu, H. Situation analysis and countermeasures of China's fly ash pollution prevention and control. Procedia Environ. Sci. 2012, 16, 690-696. [CrossRef]

38. Dong, P.; Wang, S.Y. Risks and countermeasures of the shale gas development in China. Adv. Mater. Res. 2013, 734, 1253-1256. [CrossRef]

39. Hu, D.; Xu, S. Opportunity, challenges and policy choices for China on the development of shale gas. Energy Policy 2013, 60, 21-26. [CrossRef]

40. Pi, G.; Dong, X.; Dong, C.; Guo, J.; Ma, Z. The status, obstacles and policy recommendations of shale gas development in China. Sustainability 2015, 7, 2353-2372. [CrossRef]

41. Yao, Z.; Xia, M.; Sarker, P.K.; Chen, T. A review of the alumina recovery from coal fly ash, with a focus in China. Fuel 2014, 120, 74-85. [CrossRef]

42. Wang, C.; Li, J.; Wang, L.; Sun, X. Study on adsorption of $\mathrm{Cr}(\mathrm{VI})$ using singlephase zeolites synthesized from fly ash. Chin. J. Environ. Eng. 2008, 2, 1121-1126.

43. Ram, L.; Masto, R. Fly ash for soil amelioration: A review on the influence of ash blending with inorganic and organic amendments. Earth Sci. Rev. 2014, 128, 52-74. [CrossRef]

44. Singh, J.; Mantha, S.S.; Phalle, V.M. Characterizing domestic electricity consumption in the indian urban household sector. Energy Build. 2018, 170, 74-82. [CrossRef]

45. Singh, R.; Gupta, N. Value added utilization of fly ash-prospective and sustainable solutions. Int. J. Appl. Sci. Eng. Res. 2014, 3, 1-16.

46. Surabhi. Fly ash in India: Generation vis-à-vis Utilization and Global perspective. Int. J. Appl. Chem. 2017, 13, 29-52.

47. Parab, N.; Mishra, S.; Bhonde, S. Prospects of bulk utilization of fly ash in agriculture for integrated nutrient management. Bull. Nat. Inst. Ecol. 2012, 23, 31-46.

48. Kalra, N.; Harit, R.; Sharma, S. Effect of flyash incorporation on soil properties of texturally variant soils. Bioresour. Technol. 2000, 75, 91-93. [CrossRef]

49. Yeledhalli, N.; Prakash, S.; Gurumurthy, S.; Ravi, M. Coal fly ash as modifier of physico-chemical and biological properties of soil. Karnataka J. Agric. Sci. 2010, 20, 531-534. 
50. Garg, R.N.; Pathak, H.; Das, D.; Tomar, R. Use of flyash and biogas slurry for improving wheat yield and physical properties of soil. Environ. Monit. Assess. 2005, 107, 1-9. [CrossRef] [PubMed]

51. Dhadse, S.; Kumari, P.; Bhagia, L. Fly ash characterization, utilization and government initiatives in India -A review. J. Sci. Ind. Res. 2008, 67, 11-18.

52. Dermatas, D.; Meng, X. Utilization of fly ash for stabilization/solidification of heavy metal contaminated soils. Eng. Geol. 2003, 70, 377-394. [CrossRef]

53. Production and Use of Coal Combustion Products in the U.S. Market Forecast through 2033. Prepared by: American road \& Transportation builders association. Prepared for: American coal ash association. June 2015. Available online: https://www.acaa-usa.org/Portals/9/Files/PDFs/ReferenceLibrary/ARTBA-finalhistorical.compressed.pdf (accessed on 3 June 2015).

54. Kishor, P.; Ghosh, A.; Kumar, D. Use of flyash in agriculture: A way to improve soil fertility and its productivity. Asian J. Agric. Res. 2010, 4, 1-14. [CrossRef]

55. Kolbe, J.L.; Lee, L.S.; Jafvert, C.T.; Murarka, I.P. Proceedings of the Use of Alkaline Coal Ash for Reclamation of a Former Strip Mine, World of Coal Ash (WOCA) Conference, Denver, CO, USA, 9-12 May 2011; pp. 1-15.

56. Grubb, D.G.; Guimaraes, M.A.S.; Valencia, R. Phosphate immobilization using an acidic type F fly ash. J. Hazard. Mater. 2000, 76, 217-236. [CrossRef]

57. Nyambura, M.G.; Mugera, G.W.; Felicia, P.L.; Gathura, N.P. Carbonation of brine impacted fractionated coal fly ash: Implications for $\mathrm{CO}_{2}$ sequestration. J. Environ. Manag. 2011, 92, 655-664. [CrossRef] [PubMed]

58. Kalaw, M.E.; Culaba, A.; Hinode, H.; Kurniawan, W.; Gallardo, S.; Promentilla, M.A. Optimizing and characterizing geopolymers from ternary blend of philippine coal fly ash, coal bottom ash and rice hull ash. Materials 2016, 9, 580. [CrossRef] [PubMed]

59. Matsunaga, T.; Kim, J.; Hardcastle, S.; Rohatgi, P. Crystallinity and selected properties of fly ash particles. Mater. Sci. Eng. A 2002, 325, 333-343. [CrossRef]

60. Safiuddin, M.; Jumaat, M.Z.; Salam, M.; Islam, M.; Hashim, R. Utilization of solid wastes in construction materials. Int. J. Phys. Sci. 2010, 5, 1952-1963.

61. Cao, J.; Dong, X.; Li, L.; Dong, Y.; Hampshire, S. Recycling of waste fly ash for production of porous mullite ceramic membrane supports with increased porosity. J. Eur. Ceram. Soc. 2014, 34, 3181-3194. [CrossRef]

62. Yang, T.; Ji, H.; Yoon, S.; Kim, B.; Park, H. Porous mullite composite with controlled pore structure processed using a freeze casting of TBA-based coal fly ash slurries. Resour. Conserv. Recycl. 2010, 54, 816-820. [CrossRef]

63. Kutchko, B.G.; Kim, A.G. Fly ash characterization by SEM-EDS. Fuel 2006, 85, 2537-2544. [CrossRef]

64. Külaots, I.; Hurt, R.H.; Suuberg, E.M. Size distribution of unburned carbon in coal fly ash and its implications. Fuel 2004, 83, 223-230. [CrossRef]

65. Zhu, Z.; Wang, X.; Dai, S.; Huang, B.; He, Q. Fractional characteristics of coal fly ash for beneficial use. J. Mater. Civ. Eng. 2012, 25, 63-69. [CrossRef]

66. Vassilev, S.V.; Menendez, R.; Alvarez, D.; Diaz-Somoano, M.; Martinez-Tarazona, M.R. Phase-mineral and chemical composition of coal fly ashes as a basis for their multicomponent utilization. 1. Characterization of feed coals and fly ashes $\star$. Fuel 2003, 82, 1793-1811. [CrossRef]

67. Vassilev, S.V.; Menendez, R. Phase-mineral and chemical composition of coal fly ashes as a basis for their multicomponent utilization. 4. Characterization of heavy concentrates and improved fly ash residues. Fuel 2005, 84, 973-991. [CrossRef]

68. Vassilev, S.V.; Vassileva, C.G. Methods for characterization of composition of fly ashes from coal-fired power stations: A critical overview. Energy Fuels 2005, 19, 1084-1098. [CrossRef]

69. Sarode, D.B.; Jadhav, R.N.; Khatik, V.A.; Ingle, S.T.; Attarde, S.B. Extraction and leaching of heavy metals from thermal power plant fly ash and its admixtures. Polish J. Environ. Stud. 2010, 6, 1325-1330.

70. Polat, H.; Vengosh, A.; Pankratov, I.; Polat, M. A new methodology for removal of boron from water by coal and fly ash. Desalination 2004, 164, 173-188. [CrossRef]

71. Akar, G.; Polat, M.; Galecki, G.; Ipekoglu, U. Leaching behavior of selected trace elements in coal fly ash samples from Yenikoy coal-fired power plants. Fuel Process. Technol. 2012, 104, 50-56. [CrossRef]

72. Sushil, S.; Batra, V.S. Analysis of fly ash heavy metal content and disposal in three thermal power plants in india. Fuel 2006, 85, 2676-2679. [CrossRef]

73. Fan, M.; Brown, R.C. Comparison of the loss-on-ignition and thermogravimetric analysis techniques in measuring unburned carbon in coal fly ash. Energy Fuels 2001, 15, 1414-1417. [CrossRef] 
74. Querol, X.; Umaña, J.C.; Plana, F.; Alastuey, A.; Lopez-Soler, A.; Medinaceli, A.; Valero, A.; Domingo, M.J.; Garcia-Rojo, E. Synthesis of zeolites from fly ash at pilot plant scale. Examples of potential applications. Fuel 2001, 80, 857-865. [CrossRef]

75. Inada, M.; Tsujimoto, H.; Eguchi, Y.; Enomoto, N.; Hojo, J. Microwave-assisted zeolite synthesis from coal fly ash in hydrothermal process. Fuel 2005, 84, 1482-1486. [CrossRef]

76. Fernández-Jiménez, A.; Palomo, A. Mid-infrared spectroscopic studies of alkali-activated fly ash structure. Microporous Mesoporous Mater. 2005, 86, 207-214. [CrossRef]

77. Wang, S.; Boyjoo, Y.; Choueib, A.; Zhu, Z. Removal of dyes from aqueous solution using fly ash and red mud. Water Res. 2005, 39, 129-138. [CrossRef] [PubMed]

78. Montes-Hernandez, G.; Perez-Lopez, R.; Renard, F.; Nieto, J.; Charlet, L. Mineral sequestration of $\mathrm{CO}_{2}$ by aqueous carbonation of coal combustion fly-ash. J. Hazard. Mater. 2009, 161, 1347-1354. [CrossRef] [PubMed]

79. Belviso, C. State-of-the-art applications of fly ash from coal and biomass: A focus on zeolite synthesis processes and issues. Prog. Energy Combust. Sci. 2018, 65, 109-135. [CrossRef]

80. Wang, S.; Ma, Q.; Zhu, Z.H. Characteristics of coal fly ash and adsorption application. Fuel 2008, 87, 3469-3473. [CrossRef]

81. Ge, J.C.; Kim, H.Y.; Yoon, S.K.; Choi, N.J. Reducing volatile organic compound emissions from diesel engines using canola oil biodiesel fuel and blends. Fuel 2018, 218, 266-274. [CrossRef]

82. Yilmaz, N.; Davis, S.M. Polycyclic aromatic hydrocarbon (PAH) formation in a diesel engine fueled with diesel, biodiesel and biodiesel/n-butanol blends. Fuel 2016, 181, 729-740. [CrossRef]

83. Li, G.; Wei, W.; Shao, X.; Nie, L.; Wang, H.; Yan, X.; Zhang, R. A comprehensive classification method for VOC emission sources to tackle air pollution based on VOC species reactivity and emission amounts. J. Environ. Sci. 2018, 67, 78-88. [CrossRef] [PubMed]

84. Malakar, S.; Saha, P.D.; Baskaran, D.; Rajamanickam, R. Comparative study of biofiltration process for treatment of VOCs emission from petroleum refinery wastewater-A review. Environ. Technol. Innov. 2017, 8, 441-461. [CrossRef]

85. Lee, S.; Lam, S.; Fai, H.K. Characterization of VOCs, ozone, and PM10 emissions from office equipment in an environmental chamber. Build. Environ. 2001, 36, 837-842. [CrossRef]

86. Atkinson, R. Atmospheric chemistry of VOCs and NOx. Atmos. Environ. 2000, 34, 2063-2101. [CrossRef]

87. Sakai, N.; Yamamoto, S.; Matsui, Y.; Khan, M.F.; Latif, M.T.; Mohd, M.A.; Yoneda, M. Characterization and source profiling of volatile organic compounds in indoor air of private residences in Selangor state, Malaysia. Sci. Total Environ. 2017, 586, 1279-1286. [CrossRef] [PubMed]

88. Ge, J.C.; Choi, N.J. Fabrication of functional polyurethane/rare earth nanocomposite membranes by electrospinning and its VOCs absorption capacity from air. Nanomaterials 2017, 7, 60. [CrossRef] [PubMed]

89. Mendell, M.J. Indoor residential chemical emissions as risk factors for respiratory and allergic effects in children: A review. Indoor Air 2007, 17, 259-277. [CrossRef] [PubMed]

90. Kim, H.-J.; Yoon, J.-W.; Choi, K.-I.; Jang, H.W.; Umar, A.; Lee, J.-H. Ultraselective and sensitive detection of xylene and toluene for monitoring indoor air pollution using $\mathrm{Cr}$-doped $\mathrm{NiO}$ hierarchical nanostructures. Nanoscale 2013, 5, 7066-7073. [CrossRef] [PubMed]

91. Rayalu, S.; Meshram, S.; Biniwale, R.B.; Srivasatava, A.; Jadhav, P.; Devotta, S. Volatile organic carbon monitoring in indoor environment using a versatile hydrophobic flyash-based zeolite as adsorbent. Curr. Sci. 2006, 497-503.

92. Guo, H.; Lee, S.; Li, W.; Cao, J. Source characterization of btex in indoor microenvironments in Hong Kong. Atmos. Environ. 2003, 37, 73-82. [CrossRef]

93. Barna, M.; Lamb, B.; Westberg, H. Modeling the effects of VOC/NOx emissions on ozone synthesis in the cascadia airshed of the pacific northwest. J. Air Waste Manag. Assoc. 2001, 51, 1021-1034. [CrossRef] [PubMed]

94. Kim, M.J.; Park, R.J.; Kim, J.-J. Urban air quality modeling with full $\mathrm{O}_{3}-\mathrm{NOx}-\mathrm{VOC}$ chemistry: Implications for $\mathrm{O}_{3}$ and $\mathrm{PM}$ air quality in a street canyon. Atmos. Environ. 2012, 47, 330-340. [CrossRef]

95. Shao, M.; Zhang, Y.; Zeng, L.; Tang, X.; Zhang, J.; Zhong, L.; Wang, B. Ground-level ozone in the pearl river delta and the roles of VOC and NOx in its production. J. Environ. Manag. 2009, 90, 512-518. [CrossRef] [PubMed]

96. Wei, W.; Cheng, S.; Li, G.; Wang, G.; Wang, H. Characteristics of ozone and ozone precursors (VOCs and NOx) around a petroleum refinery in Beijing, China. J. Environ. Sci. 2014, 26, 332-342. [CrossRef] 
97. Zhang, X.; Gao, B.; Creamer, A.E.; Cao, C.; Li, Y. Adsorption of VOCs onto engineered carbon materials: A review. J. Hazard. Mater. 2017, 338, 102-123. [CrossRef] [PubMed]

98. Seo, J.; Kato, S.; Ataka, Y.; Chino, S. Performance test for evaluating the reduction of VOCs in rooms and evaluating the lifetime of sorptive building materials. Build. Environ. 2009, 44, 207-215. [CrossRef]

99. Chmielewski, A.; Ostapczuk, A.; Zimek, Z.; Licki, J.; Kubica, K. Reduction of VOCs in flue gas from coal combustion by electron beam treatment. Radiat. Phys. Chem. 2002, 63, 653-655. [CrossRef]

100. Kim, S. The reduction of formaldehyde and VOCs emission from wood-based flooring by green adhesive using cashew nut shell liquid (CNSL). J. Hazard. Mater. 2010, 182, 919-922. [CrossRef] [PubMed]

101. Suresh, S.; Vijayalakshmi, G.; Rajmohan, B.; Subbaramaiah, V. Adsorption of benzene vapor onto activated biomass from cashew nut shell: Batch and column study. Recent Patents Chem. Eng. 2012, 5, 116-133. [CrossRef]

102. Tseng, T.K.; Lin, Y.S.; Chen, Y.J.; Chu, H. A review of photocatalysts prepared by sol-gel method for VOCs removal. Int. J. Mol. Sci. 2010, 11, 2336-2361. [CrossRef] [PubMed]

103. Hu, C.; Zhu, Q.; Jiang, Z.; Zhang, Y.; Wang, Y. Preparation and formation mechanism of mesoporous $\mathrm{CuO}-\mathrm{CeO}_{2}$ mixed oxides with excellent catalytic performance for removal of VOCs. Microporous Mesoporous Mater. 2008, 113, 427-434. [CrossRef]

104. Belkouch, J.; Ould-Dris, A.; Taouk, B. Removal of hazardous chlorinated VOCs over Mn-Cu mixed oxide based catalyst. J. Hazard. Mater. 2009, 169, 758-765.

105. Kim, S.C.; Shim, W.G. Catalytic combustion of VOCs over a series of manganese oxide catalysts. Appl. Catal. B 2010, 98, 180-185. [CrossRef]

106. Scire, S.; Minico, S.; Crisafulli, C.; Satriano, C.; Pistone, A. Catalytic combustion of volatile organic compounds on gold/cerium oxide catalysts. Appl. Catal. B 2003, 40, 43-49. [CrossRef]

107. Liotta, L. Catalytic oxidation of volatile organic compounds on supported noble metals. Appl. Catal. B 2010, 100, 403-412. [CrossRef]

108. Chuang, C.; Chiang, P.; Chang, E. Modeling VOCs adsorption onto activated carbon. Chemosphere 2003, 53, 17-27. [CrossRef]

109. Chiang, Y.-C.; Chiang, P.-C.; Huang, C.-P. Effects of pore structure and temperature on VOC adsorption on activated carbon. Carbon 2001, 39, 523-534. [CrossRef]

110. Li, L.; Liu, S.; Liu, J. Surface modification of coconut shell based activated carbon for the improvement of hydrophobic VOC removal. J. Hazard. Mater. 2011, 192, 683-690. [CrossRef] [PubMed]

111. Das, D.; Gaur, V.; Verma, N. Removal of volatile organic compound by activated carbon fiber. Carbon 2004, 42, 2949-2962. [CrossRef]

112. Tsai, J.-H.; Chiang, H.-M.; Huang, G.-Y.; Chiang, H.-L. Adsorption characteristics of acetone, chloroform and acetonitrile on sludge-derived adsorbent, commercial granular activated carbon and activated carbon fibers. J. Hazard. Mater. 2008, 154, 1183-1191. [CrossRef] [PubMed]

113. Oh, G.-Y.; Ju, Y.-W.; Jung, H.-R.; Lee, W.-J. Preparation of the novel manganese-embedded pan-based activated carbon nanofibers by electrospinning and their toluene adsorption. J. Anal. Appl. Pyrolysis 2008, 81, 211-217. [CrossRef]

114. Bai, Y.; Huang, Z.-H.; Kang, F. Synthesis of reduced graphene oxide/phenolic resin-based carbon composite ultrafine fibers and their adsorption performance for volatile organic compounds and water. J. Mater. Chem. A 2013, 1, 9536-9543. [CrossRef]

115. Liu, Y.; Hou, C.; Jiao, T.; Song, J.; Zhang, X.; Xing, R.; Zhou, J.; Zhang, L.; Peng, Q. Self-assembled AgNP-containing nanocomposites constructed by electrospinning as efficient dye photocatalyst materials for wastewater treatment. Nanomaterials 2018, 8, 35. [CrossRef] [PubMed]

116. Huang, Z.-M.; Zhang, Y.-Z.; Kotaki, M.; Ramakrishna, S. A review on polymer nanofibers by electrospinning and their applications in nanocomposites. Compos. Sci. Technol. 2003, 63, 2223-2253. [CrossRef]

117. Ahmaruzzaman, M.; Gupta, V. Application of coal fly ash in air quality management. Ind. Eng. Chem. Res. 2012, 51, 15299-15314. [CrossRef]

118. Qian, Q.; Gong, C.; Zhang, Z.; Yuan, G. Removal of VOCs by activated carbon microspheres derived from polymer: A comparative study. Adsorption 2015, 21, 333-341. [CrossRef]

119. Huang, Z.-H.; Kang, F.; Zheng, Y.-P.; Yang, J.-B.; Liang, K.-M. Adsorption of trace polar methy-ethyl-ketone and non-polar benzene vapors on viscose rayon-based activated carbon fibers. Carbon 2002, 40, 1363-1367. [CrossRef] 
120. Wang, W.; Zhao, Z.; Liu, F.; Wang, S. Study of NO/NOx removal from flue gas contained fly ash and water vapor by pulsed corona discharge. J. Electrostat. 2005, 63, 155-164. [CrossRef]

121. Rokni, E.; Panahi, A.; Ren, X.; Levendis, Y.A. Curtailing the generation of sulfur dioxide and nitrogen oxide emissions by blending and oxy-combustion of coals. Fuel 2016, 181, 772-784. [CrossRef]

122. Rubio, B.; Izquierdo, M.T.; Mayoral, M.C.; Bona, M.T.; Andres, J.M. Unburnt carbon from coal fly ashes as a precursor of activated carbon for nitric oxide removal. J. Hazard. Mater. 2007, 143, 561-566. [CrossRef] [PubMed]

123. Rubel, A.; Andrews, R.; Gonzalez, R.; Groppo, J.; Robl, T. Adsorption of Hg and NOx on coal by-products. Fuel 2005, 84, 911-916. [CrossRef]

124. Hwang, J.; Sun, X.; Li, Z. Unburned carbon from fly ash for mercury adsorption: I. Separation and characterization of unburned carbon. J. Miner. Mater. Charact. Eng. 2002, 1, 39. [CrossRef]

125. Mehmood, S.; Reddy, B.V.; Rosen, M.A. Energy analysis of a biomass co-firing based pulverized coal power generation system. Sustainability 2012, 4, 462-490. [CrossRef]

126. Bukhari, S.S.; Behin, J.; Kazemian, H.; Rohani, S. Conversion of coal fly ash to zeolite utilizing microwave and ultrasound energies: A review. Fuel 2015, 140, 250-266. [CrossRef]

127. Zhang, H.; Zhang, B.; Bi, J. More efforts, more benefits: Air pollutant control of coal-fired power plants in China. Energy 2015, 80, 1-9. [CrossRef]

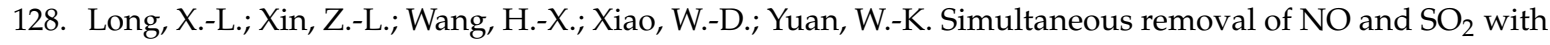
hexamminecobalt (II) solution coupled with the hexamminecobalt (II) regeneration catalyzed by activated carbon. Appl. Catal. B 2004, 54, 25-32. [CrossRef]

129. Liu, Y.x.; Zhang, J. Photochemical oxidation removal of $\mathrm{NO}$ and $\mathrm{SO}_{2}$ from simulated flue gas of coal-fired power plants by wet scrubbing using $\mathrm{UV} / \mathrm{H}_{2} \mathrm{O}_{2}$ advanced oxidation process. Ind. Eng. Chem. Res. 2011, 50, 3836-3841. [CrossRef]

130. Srivastava, R.; Miller, C.; Erickson, C.; Jambhekar, R. Emissions of sulfur trioxide from coal-fired power plants. J. Air Waste Manag. Assoc. 2004, 54, 750-762. [CrossRef]

131. Ishizuka, T.; Tsuchiai, H.; Murayama, T.; Tanaka, T.; Hattori, H. Preparation of active absorbent for dry-type flue gas desulfurization from calcium oxide, coal fly ash, and gypsum. Ind. Eng. Chem. Res. 2000, 39, 1390-1396. [CrossRef]

132. Renedo, M.; Fernandez, J. Preparation, characterization, and calcium utilization of fly ash $/ \mathrm{Ca}(\mathrm{OH})_{2}$ sorbents for dry desulfurization at low temperature. Ind. Eng. Chem. Res. 2002, 41, 2412-2417. [CrossRef]

133. Lin, R.-B.; Shih, S.-M.; Liu, C.-F. Characteristics and reactivities of $\mathrm{Ca}(\mathrm{OH})_{2} /$ silica fume sorbents for low-temperature flue gas desulfurization. Chem. Eng. Sci. 2003, 58, 3659-3668. [CrossRef]

134. Lee, K.; Mohamed, A.; Bhatia, S.; Chu, K. Removal of sulfur dioxide by fly ash $/ \mathrm{CaO} / \mathrm{CaSO}_{4}$ sorbents. Chem. Eng. J. 2005, 114, 171-177. [CrossRef]

135. Lee, K.T.; Bhatia, S.; Mohamed, A.R. Preparation and characterization of sorbents prepared from ash (waste material) for sulfur dioxide $\left(\mathrm{SO}_{2}\right)$ removal. J. Mater. Cycles Waste Manag. 2005, 7, 16-23. [CrossRef]

136. Lin, R.-B.; Shih, S.-M.; Liu, C.-F. Structural properties and reactivities of $\mathrm{Ca}(\mathrm{OH})_{2} / \mathrm{fly}$ ash sorbents for flue gas desulfurization. Ind. Eng. Chem. Res. 2003, 42, 1350-1356. [CrossRef]

137. Duruibe, J.; Ogwuegbu, M.; Egwurugwu, J. Heavy metal pollution and human biotoxic effects. Int. J. Phys. Sci. 2007, 2, 112-118.

138. Wang, S.-L.; Xu, X.-R.; Sun, Y.-X.; Liu, J.-L.; Li, H.-B. Heavy metal pollution in coastal areas of south China: A review. Mar. Pollut. Bull. 2013, 76,7-15. [CrossRef] [PubMed]

139. Fu, F.; Wang, Q. Removal of heavy metal ions from wastewaters: A review. J. Environ. Manag. 2011, 92, 407-418. [CrossRef] [PubMed]

140. Rios, C.A.; Williams, C.D.; Roberts, C.L. Removal of heavy metals from acid mine drainage (AMD) using coal fly ash, natural clinker and synthetic zeolites. J. Hazard. Mater. 2008, 156, 23-35. [CrossRef] [PubMed]

141. Huisman, J.L.; Schouten, G.; Schultz, C. Biologically produced sulphide for purification of process streams, effluent treatment and recovery of metals in the metal and mining industry. Hydrometallurgy 2006, 83, 106-113. [CrossRef]

142. Amuda, O.; Giwa, A.; Bello, I. Removal of heavy metal from industrial wastewater using modified activated coconut shell carbon. BioChem. Eng. J. 2007, 36, 174-181. [CrossRef]

143. Edelstein, M.; Ben-Hur, M. Heavy metals and metalloids: Sources, risks and strategies to reduce their accumulation in horticultural crops. Sci. Hortic. 2018, 234, 431-444. [CrossRef] 
144. Cho, H.; Oh, D.; Kim, K. A study on removal characteristics of heavy metals from aqueous solution by fly ash. J. Hazard. Mater. 2005, 127, 187-195. [CrossRef] [PubMed]

145. Hui, K.; Chao, C.Y.H.; Kot, S. Removal of mixed heavy metal ions in wastewater by zeolite $4 \mathrm{~A}$ and residual products from recycled coal fly ash. J. Hazard. Mater. 2005, 127, 89-101. [CrossRef] [PubMed]

146. Itskos, G.; Koukouzas, N.; Vasilatos, C.; Megremi, I.; Moutsatsou, A. Comparative uptake study of toxic elements from aqueous media by the different particle-size-fractions of fly ash. J. Hazard. Mater. 2010, 183, 787-792. [CrossRef] [PubMed]

147. Babel, S.; Kurniawan, T.A. Low-cost adsorbents for heavy metals uptake from contaminated water: A review. J. Hazard. Mater. 2003, 97, 219-243. [CrossRef]

148. Weng, C.-H.; Huang, C. Adsorption characteristics of Zn(II) from dilute aqueous solution by fly ash. Colloids Surf. A 2004, 247, 137-143. [CrossRef]

149. Salam, O.E.A.; Reiad, N.A.; ElShafei, M.M. A study of the removal characteristics of heavy metals from wastewater by low-cost adsorbents. J. Adv. Res. 2011, 2, 297-303. [CrossRef]

150. Nascimento, M.; Soares, P.S.M.; de Souza, V.P. Adsorption of heavy metal cations using coal fly ash modified by hydrothermal method. Fuel 2009, 88, 1714-1719. [CrossRef]

151. Kandel, S.; Vogel, J.; Penn, C.; Brown, G. Phosphorus retention by fly ash amended filter media in aged bioretention cells. Water 2017, 9, 746. [CrossRef]

152. Yildiz, E. Phosphate removal from water by fly ash using crossflow microfiltration. Sep. Purif. Technol. 2004, 35, 241-252. [CrossRef]

153. Agyei, N.M.; Strydom, C.; Potgieter, J. The removal of phosphate ions from aqueous solution by fly ash, slag, ordinary portland cement and related blends. Cem. Concr. Res. 2002, 32, 1889-1897. [CrossRef]

154. Chen, J.; Kong, H.; Wu, D.; Chen, X.; Zhang, D.; Sun, Z. Phosphate immobilization from aqueous solution by fly ashes in relation to their composition. J. Hazard. Mater. 2007, 139, 293-300. [CrossRef] [PubMed]

155. Oguz, E. Sorption of phosphate from solid/liquid interface by fly ash. Colloids Surf. A 2005, 262, $113-117$. [CrossRef]

156. Xu, X.; Li, Q.; Cui, H.; Pang, J.; Sun, L.; An, H.; Zhai, J. Adsorption of fluoride from aqueous solution on magnesia-loaded fly ash cenospheres. Desalination 2011, 272, 233-239. [CrossRef]

157. Ahmaruzzaman, M. Adsorption of phenolic compounds on low-cost adsorbents: A review. Adv. Colloid Interface Sci. 2008, 143, 48-67. [CrossRef] [PubMed]

158. Kao, P.-C.; Tzeng, J.-H.; Huang, T.-L. Removal of chlorophenols from aqueous solution by fly ash. J. Hazard. Mater. 2000, 76, 237-249. [CrossRef]

159. Matheswaran, M.; Karunanithi, T. Adsorption of chrysoidine R by using fly ash in batch process. J. Hazard. Mater. 2007, 145, 154-161. [CrossRef] [PubMed]

160. Mohan, D.; Singh, K.P.; Singh, G.; Kumar, K. Removal of dyes from wastewater using flyash, a low-cost adsorbent. Ind. Eng. Chem. Res. 2002, 41, 3688-3695. [CrossRef] 